\title{
Characterizing Light-absorbing Aerosols in a Low-income Settlement in South Africa
}

\author{
Nopasika A. Xulu ${ }^{1 *}$, Stuart J. Piketh ${ }^{1}$, Gregor T. Feig ${ }^{3,5 \dagger}$, Daniel A. Lack ${ }^{4}$, \\ Rebecca M. Garland ${ }^{1,2}$
}

\author{
${ }^{1}$ Unit for Environmental Sciences and Management, North-West University, Potchefstroom, 2520, South Africa \\ ${ }^{2}$ Natural Resources and the Environment, Council for Scientific and Industrial Research, PO Box 395, Pretoria, 0001, \\ South Africa \\ ${ }^{3}$ South African Air Quality Information (SAAQIS), South African Weather Service, Pretoria, South Africa \\ ${ }^{4}$ Daniel A Lack, Transport Emissions, Air Quality and Climate, Brisbane, Queensland, Australia \\ ${ }^{5}$ Department of Geography, Geoinformatics and Meteorology, University of Pretoria, South Africa
}

\begin{abstract}
Light-absorbing aerosols, particularly black carbon (BC), have significant impacts on human health and the climate. They are also the least-studied fraction of atmospheric particles, particularly in residential areas of southern Africa. The optical characteristics of ground-based light-absorbing aerosols from Kwadela Township in South Africa are investigated in this study. Daily averaged ambient $\mathrm{PM}_{2.5}$ highest levels were $51.39 \mu \mathrm{g} \mathrm{m}^{-3}$ and $32.18 \mu \mathrm{g} \mathrm{m}^{-3}$, whereas hourly averages peaked at $61.31 \mu \mathrm{g} \mathrm{m}^{-3}$ and $34.69 \mu \mathrm{g} \mathrm{m}^{-3}$ during winter and summer, respectively. Levels of daily averaged light-absorbing aerosols were 2.9 times higher $\left(1.89 \pm 0.5 \mu \mathrm{g} \mathrm{m}^{-3}\right)$ in winter 2014 than in summer $2015\left(0.66 \pm 0.2 \mu \mathrm{g} \mathrm{m}^{-3}\right)$. In both seasons, hourly averaged levels showed bimodal diurnal cycles, which correlated with the $\mathrm{PM}_{2.5}$ diurnal patterns that indicated distinct peaks in the morning and evening. These diurnal cycle peak periods corresponded with the times of increased solid domestic fuel usage, road traffic, and also shallower boundary layer. On average, light-absorbing aerosols contributed a larger proportion of total ambient $\mathrm{PM}_{2.5}$ levels in winter $(6.5 \pm 1.0 \%)$ than in summer $(3.4 \pm 1.0 \%)$. The winter average Absorption Ångström exponent $\mathrm{AAE}_{(370 / 880 \mathrm{~nm})}(1.7 \pm 0.5)$, indicated the dominance of brown carbon $(\mathrm{BrC})$ from biofuel/biomass burning and/or low-quality coal combustion emissions. In summer, the average $\operatorname{AAE}_{(370 / 950 \mathrm{~nm})}(1.3 \pm 0.7)$, suggested the presence of $\mathrm{BC}$ and $\mathrm{BrC}$ in the mornings and evenings possibly from fossil fuel combustion sources. At midday and at night in summer, the AAE was close to 1, suggesting more BC contributions from sources such as diesel emissions during this time. A combination of $\mathrm{BC}$ and $\mathrm{BrC}$ particulates dominated on $50 \%$ and $5 \%$ of the summer days, respectively, whereas fresh BC were only measured in summer days (23\%). Residential solid-fuel and/biomass combustion are important sources of light-absorbing aerosols in this study region, with concomitant human health and environmental impacts.
\end{abstract}

Keywords: Light-absorbing aerosols; Absorption Ångström exponent; Residential solid-fuel combustion; Aethalometer; Mpumalanga; South Africa.

\section{INTRODUCTION}

Residential solid-fuel burning has been increasingly highlighted as an important source of atmospheric pollution. Solid fuel combustion provide primary energy to many lowincome communities in developing countries, including South Africa, particularly on the industrialized Highveld

\footnotetext{
${ }^{\dagger}$ Now at South African Environmental Observation Network (SAEON), South Africa.

* Corresponding author.

E-mail address: nopasikaxulu@gmail.com
}

where there is a plentiful supply of local coal (Scorgie et al., 2003; Mdluli, 2007; Pretorius et al., 2015). Domestic solidfuel combustion generates substantial amounts of air pollutants (Naidoo et al., 2014; Makonese et al., 2014), including large fractions of light-absorbing aerosols (Bergstrom et al., 2007) (both black carbon [BC] and brown carbon $[\mathrm{BrC}]$ ), which contribute to global anthropogenic carbonaceous particulate mass loading (Bond et al., 2013). Particulate matter (PM) can have an extensive impact on air quality, human health and radiative forcing, while the absorbing component can influence the radiative forcing contribution greatly, depending on absorbing capacity (Hansen, 2005). In India, the atmospheric direct radiative forcing values due to the composite aerosols $\left(+78.3,+44.9\right.$, and $\left.+45.0 \mathrm{~W} \mathrm{~m}^{-2}\right)$ and BC aerosols $\left(+42.2,+35.4\right.$ and $\left.+34.3 \mathrm{~W} \mathrm{~m}^{-2}\right)$ were estimated 
in June, July and August, respectively. These radiative forcing values corresponded with atmospheric heating rates for composite $\left(2.21,1.26\right.$ and $\left.1.26 \mathrm{~K} \mathrm{day}^{-1}\right)$ and for BC (1.19, 0.99 and $0.96 \mathrm{~K} \mathrm{day}^{-1}$ ) aerosols during June, July and August, respectively. On average, the atmospheric heating rates for $\mathrm{BC}$ aerosols were $33 \%$ lower than the heating rates of the composite particles during the study period (Tiwari et al., 2016). Cappa et al. (2008) found that even though aerosol light absorption is relatively small compared with total solar light extinction, the related impacts can be substantial, particularly on regional climate.

In this study, the term "light-absorbing aerosols" refers to a fraction of atmospheric particles that can effectively absorb the wavelengths of solar radiation investigated here (Moosmüller et al., 2009; Petzold et al., 2013). Incoming solar radiation has a range of wavelengths including ultraviolet, visible and infrared. The ultraviolet and infrared wavelengths lie within short wavelengths and long wavelengths, respectively, and are thus commonly referred to as such. Generally, aerosols absorb different wavelengths uniquely, depending on their optical properties (Yang et al., 2009; Petzold et al., 2013; Manoharan et al., 2014). In this study, the specific focus was based on light-absorbing aerosols, which absorb solar radiation within the seven wavelengths (370, 470, 520, 590, 660, 880 and $950 \mathrm{~nm})$ of visible light. These wavelengths are the wavelengths applied for light absorption analysis on the aethalometer instrument, which was used in the current research.

The main light-absorbing particulates are $\mathrm{BC}, \mathrm{BrC}$ (the absorbing fraction of organic carbon) and mineral dust (Moosmüller et al., 2009; Yang et al., 2009). These particles can directly absorb solar radiation and release it as thermal energy, leading to increased atmospheric temperatures (Cappa et al., 2008; Moosmüller et al., 2009; Wu et al., 2009; Kuik et al., 2015). Mineral dust and $\mathrm{BrC}$ are strong absorbers of short wavelengths than long wavelengths of the visible solar radiation (Moosmüller et al., 2009; Backman et al., 2014). However, mineral dust particles can also absorb long wavelengths of the visible light, depending on their source of origin and mineral composition (Petzold et al., 2009). The refractive index of $\mathrm{BC}$ causes a relative constant absorption of light wavelengths, particularly from near-ultraviolet to near-infrared region (Moosmüller et al., 2009).

The principal light-absorbing aerosol (namely, BC) (Moosmüller et al., 2009; Petzold et al., 2013) has a global average radiative forcing potential $\left(\sim 1.1 \mathrm{~W} \mathrm{~m}^{-2}\right)$, which is estimated to be $10 \%$ of anthropogenic global warming (Bond et al., 2013). Additionally, light-absorbing aerosols can reduce cloud cover (Koch and Del-Genio, 2010), serve as cloud condensation nuclei (Madhavan, 2008) and enhance the snow/ice melting rate when deposited on snow/ice (Arnott et al., 2005). These effects can alter the solar radiation balance, as increasing $\mathrm{BC}$ aerosol concentrations can lead to decrease in the amount of solar radiation reaching the ground, and thus strengthening the solar dimming effect (Badarinath et al., 2010; Kambezidis et al., 2012). Climatic effects of BC can increase by up to a factor of 1.4 when BC is mixed internally (an aerosol compositional state where an aerosol is made up of multiple components (for example, BC core with sulfate coating)) by inorganic and/or organic material (Chung et al., 2012). In addition to the climaterelated influence of light-absorbing aerosols, these particles can also increase the risk of respiratory and cardiovascularrelated diseases, with $\mathrm{BC}$ in particular, showing stronger health impacts compared with a mix of all PM (Hansen, 2005; Smith et al., 2009). Butt et al. (2015) and Lelieveld et al. (2015) showed that carbonaceous aerosols could have negative health effects, which can be five times greater than those of inorganic particles. This is because BC can effectively adsorb toxic compounds, which can then be transported into the respiratory zone of the lungs (Hansen, 2005). Diesel exhaust, -which on average comprises of $75 \% \mathrm{BC}$, is a human carcinogen (Group 1) (IARC, 2012). Although lightabsorbing particles are a pressing issue with human health and environmental importance; these aerosols are still the most poorly characterized fraction of atmospheric particles in many countries, particularly in southern Africa (Petzold et al., 2013; Maritz et al., 2015; Yan et al., 2017; Maritz, 2019). Lack of adequate information on light-absorbing particles contributes to the uncertainties associated with comprehensive assessment of the impacts of aerosols on human health and climate (Bergstrom et al., 2007; Wu et al., 2009; Yan et al., 2017; Laakso et al., 2012; Vakkari et al., 2014; Maritz et al., 2015; Maritz, 2019). Efforts to understand aerosol properties are applied increasingly worldwide (for example, Yang et al., 2009; Chakrabatry et al., 2010; Favez et al., 2010; Gadhavi and Jayaraman, 2010; Segura et al. 2014; Tiwari et al., 2016, Dumka et al., 2018) but there is still limited work done on light-absorbing aerosol fractions in southern Africa (for example, Laakso et al., 2012; Vakkari et al., 2014; Feig et al., 2015; Maritz et al., 2015; Chiloane et al., 2017; Maritz, 2019).

The focus of South African National Ambient Air Quality Standards (NAAQS) is on trace gases, $\mathrm{PM}_{2.5}$ and $\mathrm{PM}_{10}$, with compliance monitoring concentrating in urban, residential, and industrial areas. In many areas, concentrations of aerosol particles regularly exceed NAAQS levels (Khumalo, 2017). Pollution from particulate matter is generally worse in low-income residential areas with domestic fuel burning (Hersey et al., 2015). Limited studies are available on lightabsorbing aerosols, particularly in areas impacted by residential solid-fuel combustion. In a study at multiple sites in the Vaal Triangle Airshed Priority Area and Highveld Priority Area in South Africa, Feig et al. (2015) found that seasonal cycle was similar to that of general domestic solidfuel combustion particularly in low-income settlements that use solid-fuel for domestic purposes. The significance of local anthropogenic-related sources to the burden of BC was indicated by the bimodal diurnal pattern of measured $\mathrm{BC}$ with peaks in the mornings and evenings, correlating with the times when domestic burning and traffic emissions was more prominent. In general, increased air pollution can also be influenced by a strong shallow boundary layer, which is attributed to stagnant conditions and accumulation of local air pollution particularly in winter (Vaishya et al., 2017). In this same study, measured BC aerosols contributed between $6 \%$ and $12 \%$ mass to total $\mathrm{PM}_{2.5}$ mass and the highest proportions were observed during winter, signifying the 
importance of domestic fuel combustion to aerosol mass loading (Feig et al., 2015). The importance of domestic fuel combustion to aerosol mass loading was also recognized by Maritz et al. (2015) who found that BC and organic particles can contribute up to $12 \%$ and $24 \%$ to total particulate matter, respectively, at five South African sites in the Deposition of Biogeochemical Important Trace Species-IGAC DEBITS in Africa (DEBITS-IDAF) network. A study from a small unelectrified low-income settlement in Gauteng Province indicated that solid fuels (coal and wood) are mostly burnt for cooking and heating in winter and non-solid fuels (for example, paraffin and petroleum gas) were preferred during summer for cooking purposes (Naidoo et al., 2014). The majority of households in domestic fuel-burning communities (in areas close to coal mines) often burn coal for its low cost and longer-lasting dual purpose (cooking and heating), serving basic household needs during cold winter time (Friedl et al., 2008). Makonese et al. (2014) characterised coal combustion emissions through two different fire ignition methods. Results from the study indicated high emissions of fine particles coupled with smoke from the "bottom-up fire ignition" method (the order of laying paper at the bottom then wood and coal on top), compared the "top-down" method (the coal is placed at the bottom, then wood and paper on top). This research highlighted the important contribution of domestic coal combustion methods to ambient aerosol concentrations (Makonese et al., 2014). Chiloane et al. (2017) also indicated the influence of domestic fuel burning (for space heating) on BC mass loading, by demonstrating a correspondence between $\mathrm{BC}$ and ambient temperature. However, there is limited information on absorption wavelength dependence (particularly in South Africa), a parameter that is key for estimation absorbing aerosol radiative impacts on regional climate and understanding the sources of light-absorbing aerosols (Praveen et al., 2012; Backman et al., 2014).

This study examines light-absorbing aerosols from residential solid-fuel combustion in South Africa, adding novel findings to the understanding of this important particle source in this region. The proportions of light-absorbing particulates were estimated from total particulate matter mass loading in a low-income settlement, Kwadela Township, which is situated approximately $50 \mathrm{~km}$ from industrial activities. The influence of local meteorology (wind, boundary layer) was analysed to assess the interaction between these particles and daily weather features. In contrast with Feig et al. (2015), the current research is the first to study the absorption wavelength dependence of ground-level particles on a wide spectral range $(370-950 \mathrm{~nm})$ in South Africa. A seven-wavelength aethalometer instrument was deployed to analyse the absorption wavelength dependence of lightabsorbing aerosols. This information was used to estimate the dominating types of aerosols and the radiative impacts on a regional scale. Improved knowledge of aerosol properties and characterization is critical for better understanding of their impacts on human health and climate. Part of improving aerosol characterization includes understanding aerosol types and sources, particularly those that are strongly influenced by human activities (Cazorla et al., 2013).

\section{METHODS AND MATERIALS}

\section{Study Site Description}

Measurements of light-absorbing aerosols were taken at Kwadela Township, a low-income settlement $\left(26^{\circ} 27^{\prime} 48^{\prime \prime} \mathrm{S}\right.$ $29^{\circ} 39^{\prime} 50^{\prime \prime} \mathrm{E}$ ) in the Mpumalanga Highveld (Fig. 1). The Mpumalanga Highveld is the most industrialised region in South Africa, with many areas monitoring exceedances of the NAAQS (Freiman and Piketh, 2003; Laakso et al., 2012; Feig et al., 2019).

Kwadela low-income settlement comprises 984 households. The most of these families depend on solid fuels, particularly locally distributed coal, for cooking and space heating in winter, and to a lesser extent during summer (Pauw et al., 2014). The low-income settlement is located approximately $500 \mathrm{~m}$ from the N-17 national road and may also be influenced by regional air pollution from nearby towns, coal-fired power stations, petrochemical industries, mining and metallurgical industries (Schuster et al., 2016). This township was selected to specifically evaluate the relative importance of domestic solid-fuel combustion on air pollution levels.

\section{Light-absorbing Aerosols and Particulate Matter Mass Concentration Measurements}

Winter and summer sampling of light-absorbing particulates were undertaken from 18 July 2014 until 18 September 2014 and 18 February 2015 to 13 April 2015, respectively. The measurements were made with an aethalometer AE-22 (winter) and an AE-31 (summer) (USA Magee Scientific). These aethalometer instruments have been used widely to quantify light-absorbing aerosols concentrations in urban, industrial, rural and remote areas across the globe (for example, Sandradewi et al., 2008; Favez et al., 2010; Segura et al., 2014). Both instruments measure the light absorption at multiple wavelengths (AE-22 at 370 and $880 \mathrm{~nm}$ and the AE-31 at 370, 470, 520, 590, 660, 880 and $950 \mathrm{~nm}$ ) (Hansen, 2005). Light absorption measurements are related to mass concentration $\mathrm{M}_{\mathrm{bc}}\left(\mu \mathrm{g} \mathrm{m}^{-3}\right)$ of carbonaceous aerosols at each wavelength using Eq. (1) (Favez et al., 2010; Laakso et al., 2012).

$M_{b c}=\frac{\sigma_{(a b s)}}{E_{(a b s)}}$

where $\sigma_{(\mathrm{abs})}$ is the aerosol absorption coefficient $\left(\mathrm{Mm}^{-1}\right.$ or $\left.10^{-6} \mathrm{~m}^{-1}\right) ; \mathrm{E}_{(\mathrm{abs})}$ is the mass absorption efficiency of black carbon, which is $14625 / \lambda \mathrm{m}^{2} \mathrm{~g}^{-1}$ - a Magee calibration factor that was used in the current study to convert optical attenuation to BC mass concentration as recommended by Hansen (2005). This mass absorption efficiency value $\left(14625 / \lambda \mathrm{m}^{2} \mathrm{~g}^{-1}\right)$ can represent $\mathrm{BC}$ absorption at long wavelengths, and also $\mathrm{BrC}$ and dust light absorption at short wavelengths. Therefore, the computed spectral $\mathrm{BC}$ values indicate the equivalent $\mathrm{BC}$ mass (e-BC), which is the mass of total light-absorbing aerosols, as these values are also influenced by other lightabsorbing particulates such as dust and $\mathrm{BrC}$ (Dumka et al., 2019; Liakakou et al., 2020).

While a constant $\mathrm{E}_{(\mathrm{abs})}$ was used in this study, it is important 


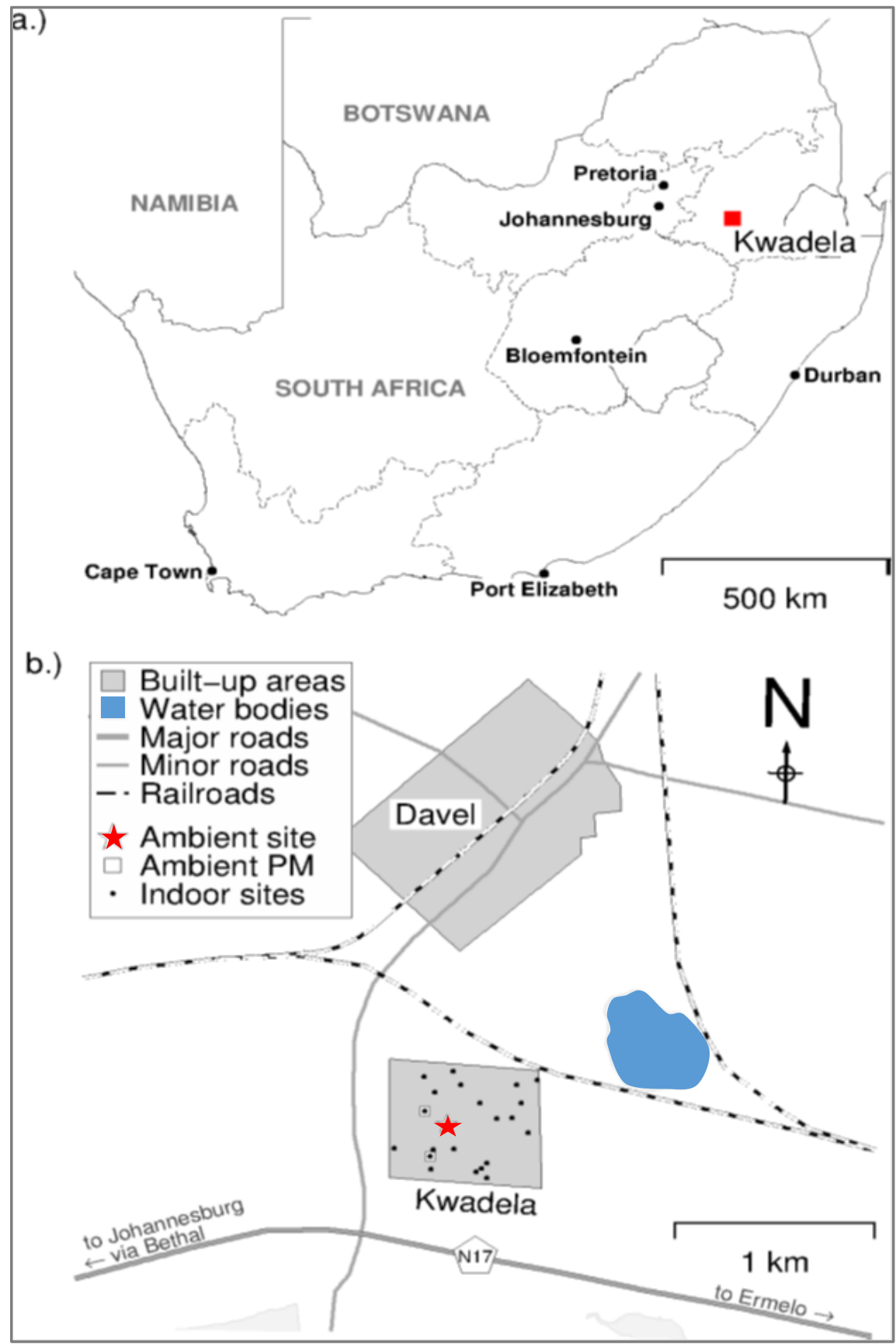

Fig. 1. (a) The location of Kwadela Township in Mpumalanga region. (b) The site of the sampling station within Kwadela settlement.

to note that $\mathrm{E}_{(\mathrm{abs})}$ values have been found to vary seasonally, can be site-specific, and depend on aerosol composition (Avino et al., 2011; Xing et al., 2014), which can in turn be influenced by meteorological conditions (Satish et al., 2017). Xing et al. (2014) found that $\mathrm{E}_{(\mathrm{abs})}$ varied seasonally, with higher values (2.1 factors higher) obtained in summer compared to other seasons (autumn, spring and winter) in the Sichuan Basin area, and the Pearl River Delta, China. This was mainly due to varying emission patterns and source types. Higher $\mathrm{E}_{(\mathrm{abs})}$ were observed from biomass burning aerosol measurements, which dominated during late summer relative to residential solid fuel combustion particulates, which dominated in winter, in Beijing-Tianjin-Hebei, Yangtze River Delta, Sichuan Basin and Pearl River Delta areas. Wang et al. (2013) also found varying $\mathrm{E}_{(\mathrm{abs})}$ values which ranged from $0.47 \mathrm{~m}^{2} \mathrm{~g}^{-1}$ to $5.15 \mathrm{~m}^{2} \mathrm{~g}^{-1}$, signifying the effect of temporal and spatial variability on $\mathrm{E}_{(\mathrm{abs})}$ measurements. $\mathrm{E}_{\text {(abs) }}$ value of $7.7 \mathrm{~m}^{2} \mathrm{~g}^{-1}$ measured at $880 \mathrm{~nm}$, generally represents pure $\mathrm{BC}$ computed by Aethalometer instruments (Dumka et al., 2018; Dumka et al., 2019). If possible, sitederived $\mathrm{E}_{(\text {(abs) }}$ values are mostly preferred for long-term lightabsorbing aerosol measurements as they can improve the accuracy of quantifying BC particulates (Wang et al., 2013). Instruments used to measure light-absorbing aerosols do 
have default $\mathrm{E}_{(\mathrm{abs})}$ values that are a function of the wavelength of light and its attenuation by the light-absorbing particles loading on the filter spot. For the aethalometer, default wavelength-specific $\mathrm{E}_{(\mathrm{abs})}$ values are generally applied (Hansen, 2005) using Eq. (2).

$$
E_{(a b s)}=\frac{\sum_{i=1}^{n} \alpha_{(a b s)-i}}{\sum_{i=1}^{n} m_{i}}
$$

where $E_{(a b s)}\left(\mathrm{m}^{2} \mathrm{~g}^{-1}\right)$ is characterized as the sum of all individual absorption cross-sections of the particles $\left(\mathrm{m}^{2}\right)$ over the sum of the mass of the particles $\left(\mathrm{m}_{\mathrm{i}}\right)$ in grams for (n) number of particles in a sample. In this study, the additional information needed to calculate a site-specific $\mathrm{E}_{(\mathrm{abs})}$ was not available, and thus the Magee recommended factor of $14625 / \lambda \mathrm{m}^{2} \mathrm{~g}^{-1}$ was used (Hansen, 2005).

Mass concentration measurements from $880 \mathrm{~nm}$ wavelength were used to compare winter and summer light-absorbing aerosol levels. The $880 \mathrm{~nm}$ wavelength is a light band where $\mathrm{BC}$ absorption is by far the most dominant, thereby limiting the influence of other absorbers (for example, $\mathrm{BrC}$ and mineral dust) (Hansen, 2005; Tiwari et al., 2014). BC is the main constituent of anthropogenic fuel combustion aerosols and a useful qualitative description of the total light-absorbing carbonaceous fraction of atmospheric aerosols (Petzold et al., 2013).

\section{Extensive Properties}

\section{Light-absorbing Aerosols Mass Concentrations}

Data collection took place in a standard operation recommended by the manufacturer with similar parameter settings on both instruments. The aethalometer instruments were housed in a mobile air-conditioned monitoring station that was located at the local primary school, close to the centre of the township (Fig. 1). The instruments were connected to a $60 \mathrm{~mm}$ glass inlet port, which was projected up to $3 \mathrm{~m}$ above the roof of the station. Both instruments were positioned in the same spot inside the measurement station in winter and summer. The inlet drew undried air continuously through the instrument inlet port and to the aethalometer at a rate of $4 \mathrm{~L} \mathrm{~min}^{-1}$. No aerosol size-cut was used for the aethalometer measurements. The manufacturer has noted that the aethalometer usually measures particles with an aerodynamic diameter $\leq 10 \mu \mathrm{m}\left(\mathrm{PM}_{10}\right)$ (Hansen, 2005) but there are possible contributions of particles with an aerodynamic diameter $>10 \mu \mathrm{m}$. BC mass concentration measurements were recorded at 5-min intervals for the entire sampling period. (Refer to Supplementary material for details on the sampling technicality using AE-31).

\section{Particulate Matter Mass Concentrations}

In addition to light-absorbing aerosol measurements, mass concentrations of particulate matter with aerodynamic size $\leq 2.5 \mu \mathrm{m}\left(\mathrm{PM}_{2.5}\right)$ and $10 \mu \mathrm{m}\left(\mathrm{PM}_{10}\right)$ were measured simultaneously at the site using a MetOne E-Bam 1020 (E-Bam) and a MetOne Bam 1020 (Bam), respectively.
These instruments use beta attenuation to determine the mass concentration of the sampled air stream. The inlets for the two fractions were supplied by the manufacturer and their efficiencies have been well documented (Schweizer $e t$ al., 2016; Mukherjee et al., 2017). The concentrations of particle loadings have been used to estimate the proportional mass of the light-absorbing aerosols. Meteorological variables (such as wind speed and direction) were also measured at the same Kwadela Township site during the two field campaigns. (Refer to Supplementary material for more details on measurements of PM mass concentrations and meteorological variables (wind speed and direction) (R.M. Young Company, 2020).

\section{Intensive Properties}

\section{Absorption Ångström Exponent}

The aerosol absorption coefficients $(\sigma)$ obtained from the aethalometer were used to determine the absorption wavelength dependence at seven different wavelengths. This parameter was applied to estimate the dominating aerosol types only during the summer sampling period. In general, the absorption wavelength dependence is quantified by the absorption Ångström exponent (AAE) computed as:

$$
A A E=-\frac{\log \left(\frac{\sigma_{1}}{\sigma_{2}}\right)}{\log \left(\frac{\lambda_{1}}{\lambda_{2}}\right)}
$$

where $\sigma_{1}, \sigma_{2}$ are the absorption coefficients $\left(\mathrm{Mm}^{-1}\right)$ at two consecutive wavelengths, $\lambda_{1}(\mathrm{~nm})$ and $\lambda_{2}(\mathrm{~nm})$.

The AAE is the negative slope of the double logarithmic plot of absorption coefficients versus wavelength (Moosmüller et al., 2009). The linearity of the slope (that is, the value of AAE) is determined by the aerosol optical properties such that $\mathrm{BC}$ is indicated by $\mathrm{AAE}=1$ (Bergstrom et al., 2007). But the presence of other light-absorbing particles (for example, BrC-related polycyclic aromatic hydrocarbons $(\mathrm{PAH})$ ) leads to stronger absorption at short wavelengths $(\leq 470 \mathrm{~nm})$, and thus stronger short wavelength dependence is indicated by AAE > 1 (Ramachandran and Rajesh, 2007). For example, wood burning-related aerosols are sensitive to short wavelengths and can be indicated by high AAE values which can range from 1.31 to 1.88 (Massabò et al., 2015; Dumka et al., 2018). The AAE measured at multiple wavelengths enables the apportionment of different light-absorbing aerosols contributing to the total mass concentration of the lightabsorbing fraction (Backman et al., 2014). In this respect, the absorption wavelength dependences were calculated at $370 / 880 \mathrm{~nm}, 370 / 590 \mathrm{~nm}, 590 / 950 \mathrm{~nm}$ and 370/950 nm, which are commonly used to analyse chemical composition of the measured light-absorbing aerosols (Favez et al., 2010; Dumka et al., 2018). The $370 / 880 \mathrm{~nm}$ and $370 / 950 \mathrm{~nm}$ pair represents the average absorption wavelength behaviour of the measured particles and has been used widely for understanding source apportionment from residential fuel combustion (for example, Sandradewi et al., 2008; Yang et al., 2009; Favez et al., 2010; Tiwari et al., 2014; Dumka et al., 2018). However, 
there is no strong consensus on the strength of the relationship between specific AAE values and specific aerosol compositions (Kaskaoutis et al., 2007). This is partly because AAE is sensitive to the correction algorithm used to correct the instrument artifacts (Petzold et al., 2013).

\section{Data Treatment}

For data consistency and validity, negative and absolute zero values from the aethalometer were regarded as invalid and thus discarded. Also, artificially large and small values arising from the relatively monotonic trend were omitted as they represent instrument malfunctioning and contribute to data noise. Such data destructions resulted from the slight random fluctuations on the voltage signal (Hansen, 2005). Correcting data noise was important because it can affect the calculations of absorption coefficient wavelength dependence (Segura et al., 2014). Approximately $1 \%$ and $31 \%$ of total winter and summer data, respectively, were discarded. Consequently, 14064 and 10568 five-minute averaged data points were used to characterize the light-absorbing aerosol fraction during winter and summer, respectively.

Several studies have shown that the aethalometer is subject to errors associated with filter-embedded scattering aerosols and shadowing effects resulting from the accumulation of aerosols on the filter spot. These artifacts are estimated to be $\pm 20 \%$ overall (Moorthy et al., 2007; Favez et al., 2010; Segura et al., 2014) and lead to uncertainties in light-absorbing aerosol mass concentration measurements (Weingartner et al., 2003; Arnott et al., 2005). The Weingartner et al. (2003) algorithm was used to correct aethalometer data at multiple wavelengths for filter-embedded scattering aerosols and shadowing effects (Roden et al., 2006; Segura et al., 2014) using Eq. (4).

$\sigma_{a b s}=\frac{\sigma_{a t n}}{C\left(R_{a t n}\right)}$

where $\sigma_{\mathrm{abs}}$ and $\sigma_{\mathrm{atn}}$ are the corrected absorption coefficient and the attenuation (uncorrected) coefficient, respectively. The constant (C) of 2.14 was adopted from Weingartner $e t$ al. (2003), which has been shown to reduce scattering errors associated with filter fibres and is wavelength independent, which is suitable for urban monitoring (Arnott et al., 2005; Sandradewi et al., 2008; Favez et al., 2010). $\mathrm{R}_{\mathrm{atn}}$ corrects the artifacts related to the decrease of light attenuation due to accumulation of particles on a filter spot and can be expressed as the shadowing effect. $\mathrm{R}_{(\mathrm{atn})}$ was determined according to Eq. (5):

$$
R_{(f, a t n)}=\left(\frac{1}{f}-1\right)\left[\frac{\ln _{(a t n)}-\ln _{(10)}}{\ln _{50}-\ln _{(10)}}+1\right]
$$

where atn corresponds to the light attenuation and $\mathrm{f}$ is the shadowing factor which corrects loading artifacts (both are unitless).

The shadowing factor (f) is calculated by minimizing the difference between the ratios of attenuation coefficients before and after filter tape advances (following Sandradewi et al., 2008; Favez et al., 2010; Segura et al., 2014).

Both aethalometers (AE-22 and AE-31) were factorycalibrated at the manufacturer (£erosol-Slovenia), while the particulate instruments were serviced prior to sampling. The flow was calibrated at the height of the instrument on site. The E-BAM 1020 and BAM 1020 undergo automatic calibrations by checking drifts, which may be influenced by external parameters such as relative humidity, temperature and barometric pressure as explained in the instrument manual.

\section{RESULTS AND DISCUSSION}

\section{General Overview of the Air Particulate Matter Air Pollution Levels in Kwadela Low-income Settlement}

Daily averaged ambient $\mathrm{PM}_{2.5}$ maximum levels in winter and summer were $51.39 \mu \mathrm{g} \mathrm{m}^{-3}$ and $32.18 \mu \mathrm{g} \mathrm{m}^{-3}$, respectively, whereas hourly averaged mass concentrations peaked at $61.31 \mu \mathrm{g} \mathrm{m}^{-3}$ and $34.69 \mu \mathrm{g} \mathrm{m}^{-3}$ during winter and summer, respectively. Winter concentrations of PM in Kwadela exceeded the South African 24-hour NAAQS for $\mathrm{PM}_{2.5}$ $\left(40 \mu \mathrm{g} \mathrm{m}^{-3}\right)$. Results from the measured light-absorbing aerosols indicated that the $\mathrm{BC}$ proportion correlated more with fine particles $\left(\mathrm{PM}_{2.5}\right)$ than with $\mathrm{PM}_{10}$, and were similar to the results reported by Feig et al. (2015). This was observed from the daily averaged $\mathrm{PM}_{2.5}$ and light-absorbing aerosol correlations, which were $r=0.79$ (winter) and $r=0.56$ (summer), respectively. The measured light-absorbing aerosols were poorly related to $\mathrm{PM}_{10}(\mathrm{r}=0.25$ in winter and $\mathrm{r}=0.23$ in summer, respectively), possibly because these coarse particles are mainly represented by dust (Yang et al., 2009), which has insignificant absorption at $880 \mathrm{~nm}$ wavelength (Ramachandran and Rajesh, 2007). Hourly averaged $\mathrm{PM}_{2.5}$ concentrations showed better correlations of $r=0.81$ (winter) and 0.76 (summer), respectively. This implies that lightabsorbing aerosols were associated with $\mathrm{PM}_{2.5}$ primary sources such as fossil fuel and biofuels and /agricultural waste burning as well as diesel exhausts (Bond et al., 2002; Roden et al., 2006; Moosmüller et al., 2009; van der Berg et al., 2015), particularly in winter.

\section{Temporal Variations of Light-absorbing Aerosol Mass Concentrations}

Daily Aerosol Mass Concentration Variations

Winter light-absorbing aerosol mass concentrations (measured at 370-950 nm wavelengths) were on average 2.9 times higher than summer levels (that is, $1.89 \pm 0.5 \mu \mathrm{g} \mathrm{m}^{-3}$ in winter and $0.66 \pm 0.2 \mu \mathrm{g} \mathrm{m}^{-3}$ in summer) and varied on a daily and seasonal time scale (Fig. 2). In winter, the maximum daily average of light-absorbing aerosol mass concentration was $3.51 \mu \mathrm{g} \mathrm{m}^{-3}$, while the minimum was $0.63 \mu \mathrm{g} \mathrm{m}^{-3}$. For summer, the maximum was $1.41 \mu \mathrm{g} \mathrm{m}^{-3}$, and the minimum was $0.37 \mu \mathrm{g} \mathrm{m}^{-3}$. These levels are high relative to those measured in some reported rural solid-fuel burning areas such as in Kenya (Gatari and Boman, 2003). The daily average mass concentrations of light-absorbing aerosols indicated that $\sim 95 \%$ of winter levels ranged between $1.5 \mu \mathrm{g} \mathrm{m}^{-3}$ and $2 \mu \mathrm{g} \mathrm{m}^{-3}$, with five-minute averages showing maximum values up to $58.91 \mathrm{\mu g} \mathrm{m}^{-3}$. $90 \%$ of daily summer levels ranged 

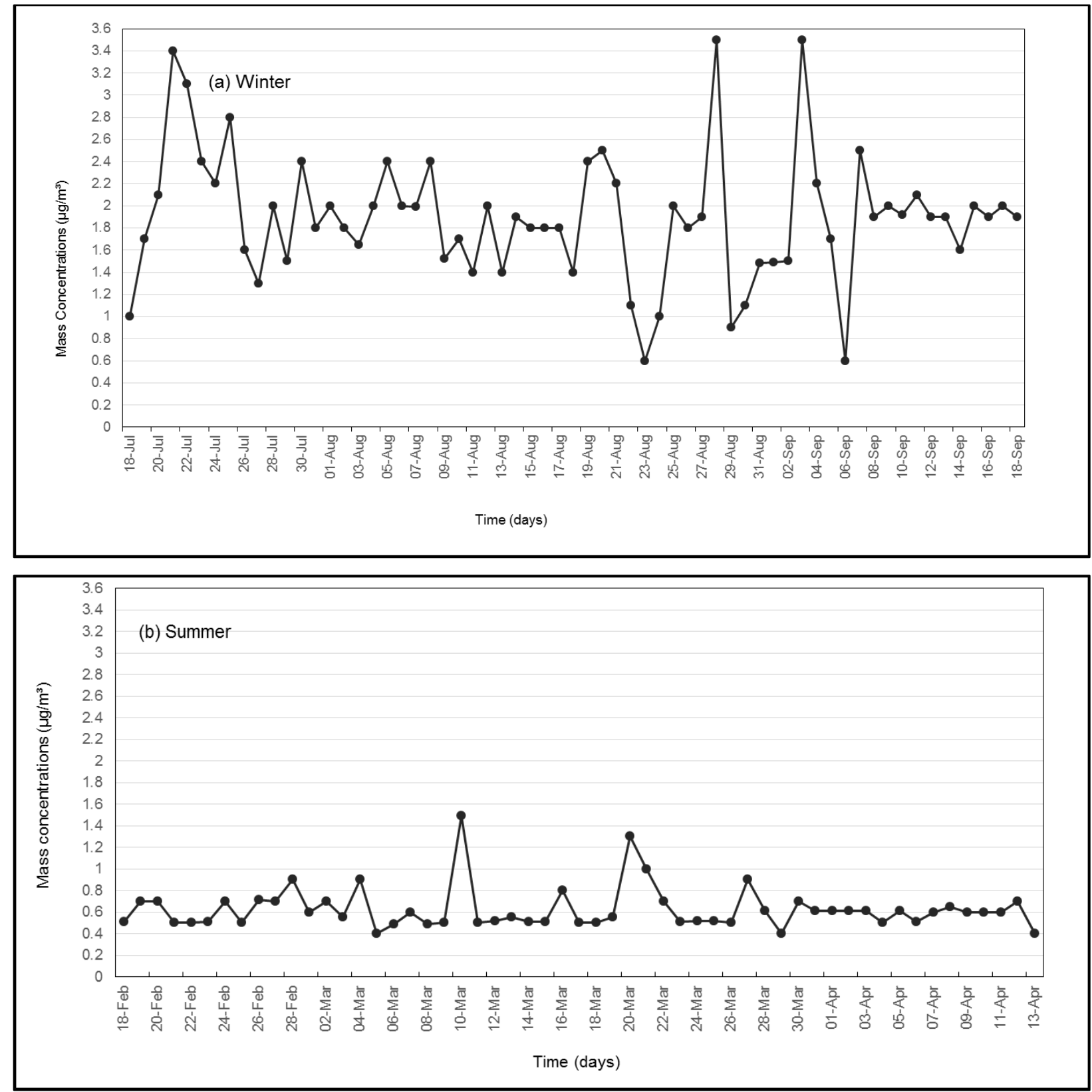

Fig. 2. Daily averaged (a) winter and (b) summer light-absorbing aerosol mass concentrations. Solid circles represent mean values.

from $0.6 \mu \mathrm{g} \mathrm{m}^{-3}$ to $0.7 \mu \mathrm{g} \mathrm{m}^{-3}$, with 5-minute averages ranging up to $36.91 \mu \mathrm{g} \mathrm{m}^{-3}$. At Welgegund (a background site, which is $100 \mathrm{~km}$ southwest of Johannesburg, Gauteng Province), BC levels ranged between 1 to $5 \mu \mathrm{g} \mathrm{m}^{-3}$ in spring and 0.3 to $0.5 \mu \mathrm{g} \mathrm{m}^{-3}$ during summer (Kuik et al., 2015).

The daily and seasonal variabilities of light-absorbing aerosol mass suggest that there were multiple sources that contributed to air pollution levels. These sources were affected by short-and long-term factors. Such sources may include combustion of solid fossil fuels (such as wood and coal) for heating and cooking; traffic emissions, and burning of biomass or waste (van der Berg et al., 2015).

Previous South African studies (Friedl et al., 2008; Lourens et al., 2011; Laakso et al., 2012) noted that solid- fuel burning-communities burn more solid fuels in winter, particularly for space heating. This practice is associated with relatively high pollution levels during winter as was observed in the Highveld area. Solid fuels (coal and wood) are predominantly burnt in winter and non-solid fuels (such as paraffin) are generally preferred in summer (Naidoo et al., 2014). Apart from the abundance of coal, the usage of solid fuels in Kwadela Township is partly due to the unreliable electricity supply, having six $>10$-hour power outages witnessed during the winter 2014 campaign and two outages during the summer sampling campaign. Generally, in this region of South Africa, more people use solid fuels for heating and for cooking because they are relatively less expensive than electricity. Moreover, coal combustion emits 
bulk heat energy for a longer period (Friedl et al., 2008). The combustion of solid fuels generates significant amounts of particles including $\mathrm{BC}$ and $\mathrm{BrC}$, which can contribute substantially to local air pollution levels (Backman et al., 2014; Tiwari et al., 2014). This seasonal dependence on fuel use and fuel type can partly explain the seasonality of lightabsorbing aerosol levels observed in Fig. 2. Moreover, relatively stagnant conditions associated with shallow boundary layer can lead to accumulation of air pollution from local sources (for example, domestic fuel combustion, biomass and waste burning, as well as vehicle emissions) particularly during the winter season. Therefore, seasonal light-absorbing aerosol levels partly highlight the importance of local fuel combustion sources on air pollution mass loading in Kwadela Township.

\section{Diurnal Aerosol Mass Concentration Distributions}

Hourly averaged light-absorbing aerosols mass concentrations indicated a bimodal diurnal cycle that peaked during the morning $\left(4.2 \mu \mathrm{g} \mathrm{m}^{-3}\right.$ and $\left.1.2 \mu \mathrm{g} \mathrm{m}^{-3}\right)$ and the afternoon $\left(5.8 \mu \mathrm{g} \mathrm{m}^{-3}\right.$ and $\left.2.1 \mu \mathrm{g} \mathrm{m}^{-3}\right)$ in winter and summer, respectively (Fig. 3). The two peaks occur at 6:00 in winter morning and 17:00 in the evening. During summer, the peaks are shorter and occur at 6:00 in the morning and 18:00

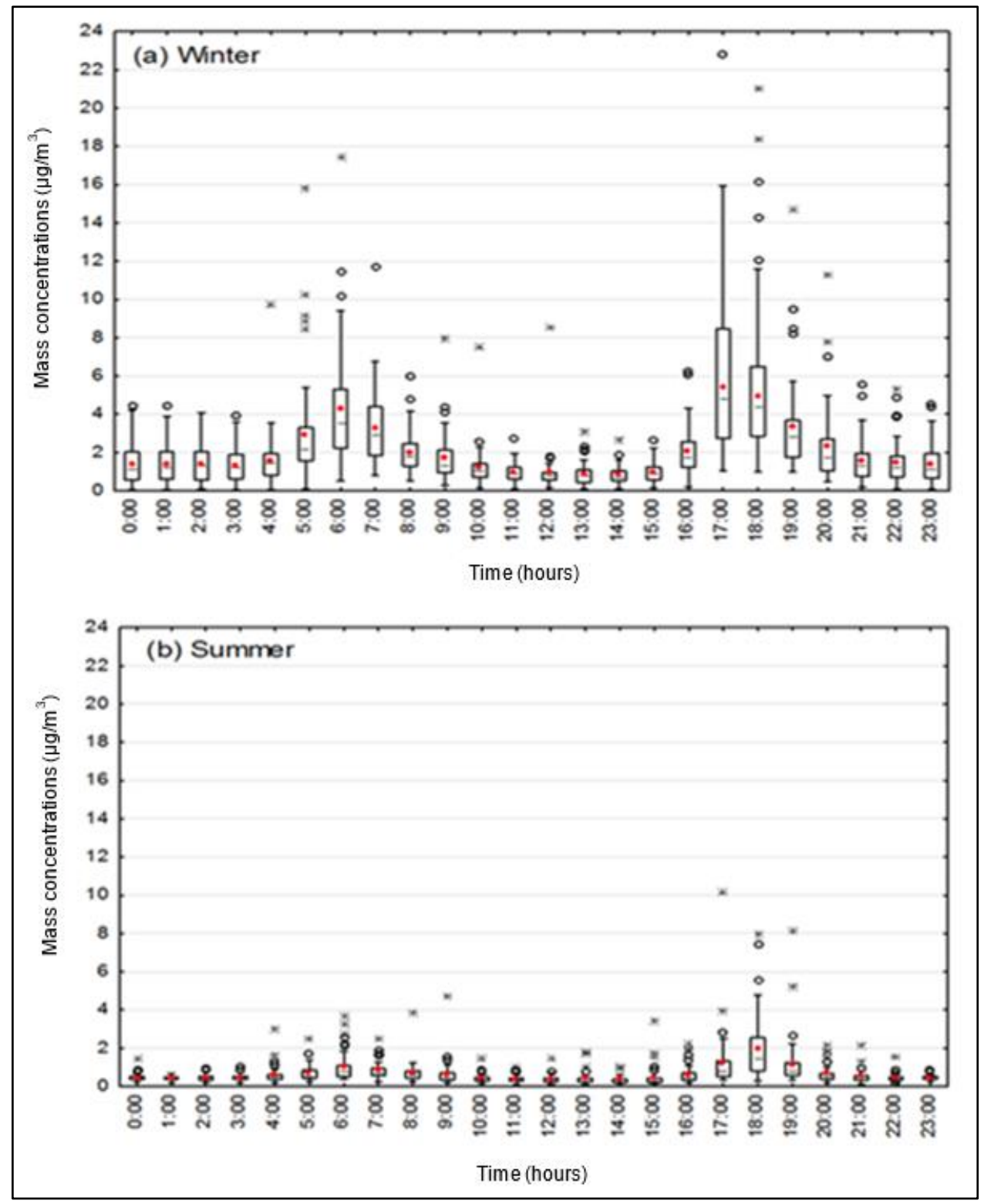

Fig. 3. The diurnal distribution of mass concentrations of light-absorbing aerosols measured during (a) winter and (b) summer. The horizontal lines represent the medians; the limits of the red black boxes are the $25^{\text {th }}$ and $75^{\text {th }}$ percentiles. The vertical line extends to the $5^{\text {th }}$ and $95^{\text {th }}$ percentiles. The stars and open dots represent extremes and outliers and the solid orange dots are mean values. The extremes and outliers are defined as the individual points plotted beyond the $5^{\text {th }}$ and the $95^{\text {th }}$ percentiles. The scales on the $y$-axis for winter and summer panels were kept the same to compare the seasonal behaviour of mass concentrations of light-absorbing aerosols. 
in the evening. The highest morning levels were observed at 06:00 in both seasons. The evening winter peak (17:00) is an hour earlier than the summer peak (18:00).

The diurnal aerosol mass concentration variations suggest the influence of local anthropogenic-related aerosol sources on light-absorbing aerosol levels. The emissions from these sources are larger in winter compared to summer and higher in the evenings relative to the mornings in both seasons. This pattern suggests the importance of anthropogenic related sources such as domestic solid fuel combustion and traffic emissions. Residential solid fuel combustion serves as an important source of energy supply for cooking and space heating in the study area and is mostly pronounced in winter and also in the mornings and afternoons, where carbonaceous fuels are burnt for cooking and space heating (Lourens et al., 2011; Laakso et al., 2012).

In general, carbonaceous fuels burnt in household cooking stoves (which are mainly used in Kwadela Township) can generate substantial amounts of particulates because of insufficient mixing of fuel with oxygen, leading to incomplete combustion process (WHO, 2012). Inadequate air supply (choked inlet) restricts the combustion rate and thus reduce fuel burning temperature, leading to minimal fuel organic content graphitization (solidification of the organic material during solid fuel combustion process) and thus promoting the production of light-absorbing aerosols with low absorption efficiency (for example, BrC). The reduced combustion efficiency, during prolonged smoldering fires in the residential cooking stoves, encourages high emission rates of $\mathrm{BrC}$ (Schuster et al., 2016; Stockwell et al., 2016). Increased air flow promotes combustion and thermal increase leading to a higher degree of organic material graphitization, favoring BC production (Bond et al., 2002). The domestic cooking stoves used in Kwadela Township are often in poor condition and thus are likely to have widely varying air flow and temperature, which can lead to incomplete fuel combustion, and thus the production of light-absorbing particulates such as BC and BrC (EPA, 2012).

Possible contributions of light-absorbing aerosol from biomass burning and agricultural waste burning can also be expected due the abundance of dry biomass during the winter season. The influence of boundary layer and differences in atmospheric mixing processes during winter and summer can also be a cause of higher winter air pollution levels compared to summer levels (Dumka et al., 2015).

The Impacts of Meteorology on Ambient Particulate Matter Mass Concentrations

A typical boundary layer height measured in the Highveld between 2012 and 2013, indicated that this layer increased from $200 \mathrm{~m}$ in the mornings (around 06:00) and reached an average of $4000 \mathrm{~m}$ at midday (09:00-13:00) mostly due to surface heating (Gierens, 2015). Measurements of a boundary layer were based on South African Weather Service (SAWS) surface and ERA-interim upper-air dataset as input in the AEROMET meteorological pre-processor done between 2009 and 2013. The relatively shallower nocturnal boundary layer acts as a sealing layer, restricting the vertical distribution of ground-level pollutants. However, reduced human activities contributed to low pollution levels from late evenings to early morning hours. The contribution from local anthropogenic sources such as solid fuel combustion and traffic emissions was responsible for the morning peak under a relatively shallow boundary layer. The increase of wind speed and temperature as the day progresses from late mornings results in the breaking of this layer, promoting vertical mixing which leads to the dispersion of pollutants and thus the decrease in surface air pollution levels (Tyson and Preston-Whyte, 2000; Verma and Desai, 2008; Gierens, 2015) such as those observed at midday (Fig. 2).

The increase of the local anthropogenic activities such as solid fuel combustion and traffic emissions, coupled with gradual reduction of the boundary layer height, resulted in the rapid increase of pollutant levels in the late afternoons. The lowest concentrations were measured at midday in both seasons, corresponding with the time when the atmospheric mixing is dominant and the local fuel combustion sources are less prevalent (Feig et al., 2014), partly due to relatively high wind-speed measured at midday during winter and summer. Temporal variations of air pollutant mass concentrations suggest that air pollution levels were influenced by multiple sources (for example, domestic solid fuel and agricultural combustion, traffic emissions as well as the suspension of particulates from unpaved road (van der Berg et al., 2015)). Diurnal mass concentration patterns indicate the influence of the sources that are stronger in the evening relative to the mornings in both seasons but more pronounced in winter than in summer; such a source is the combustion of solid fuels. In the study area, atmospheric pollutants are commonly generated from fossil fuel combustion due to insufficient electricity supply, resulting to the dependence on fossil fuel such as wood and coal for domestic energy supply. Domestic fuel combustion contributes significant amounts of air particulates particularly in winter where carbonaceous fuels are burnt for cooking and space heating. Variability in the pollution levels may also be influenced by random acute events such as veld fires (namely, wild brush fires). One such fire event took place in the farms bordering Kwadela low-income settlement and contributed to high aerosol concentrations on 28 August 2014 (3.5 $\mu \mathrm{g} \mathrm{m}^{-3}$ ) (Fig. 2), which impacted to daily fluctuations of local light-absorbing aerosol levels.

These factors emphasize the importance of local anthropogenic activities and meteorological conditions in understanding light-absorbing aerosol levels in Kwadela Township and at other similar townships on the South African Highveld. Analysis of light-absorption wavelength dependence gave a further indication of the types of lightabsorbing particulates that dominated at different times of the day.

\section{The Proportions of Light-absorbing Aerosols to Total Particulate Matter}

Light-absorbing aerosols contributed higher mass proportions of total $\mathrm{PM}_{2.5}$ in winter than in summer. Hourly averaged aerosol absorption mass concentrations proportional to $\mathrm{PM}_{2.5}$ and $\mathrm{PM}_{10}$ mass concentrations had a distinct bimodal diurnal cycle in winter and summer (Fig. 4). 

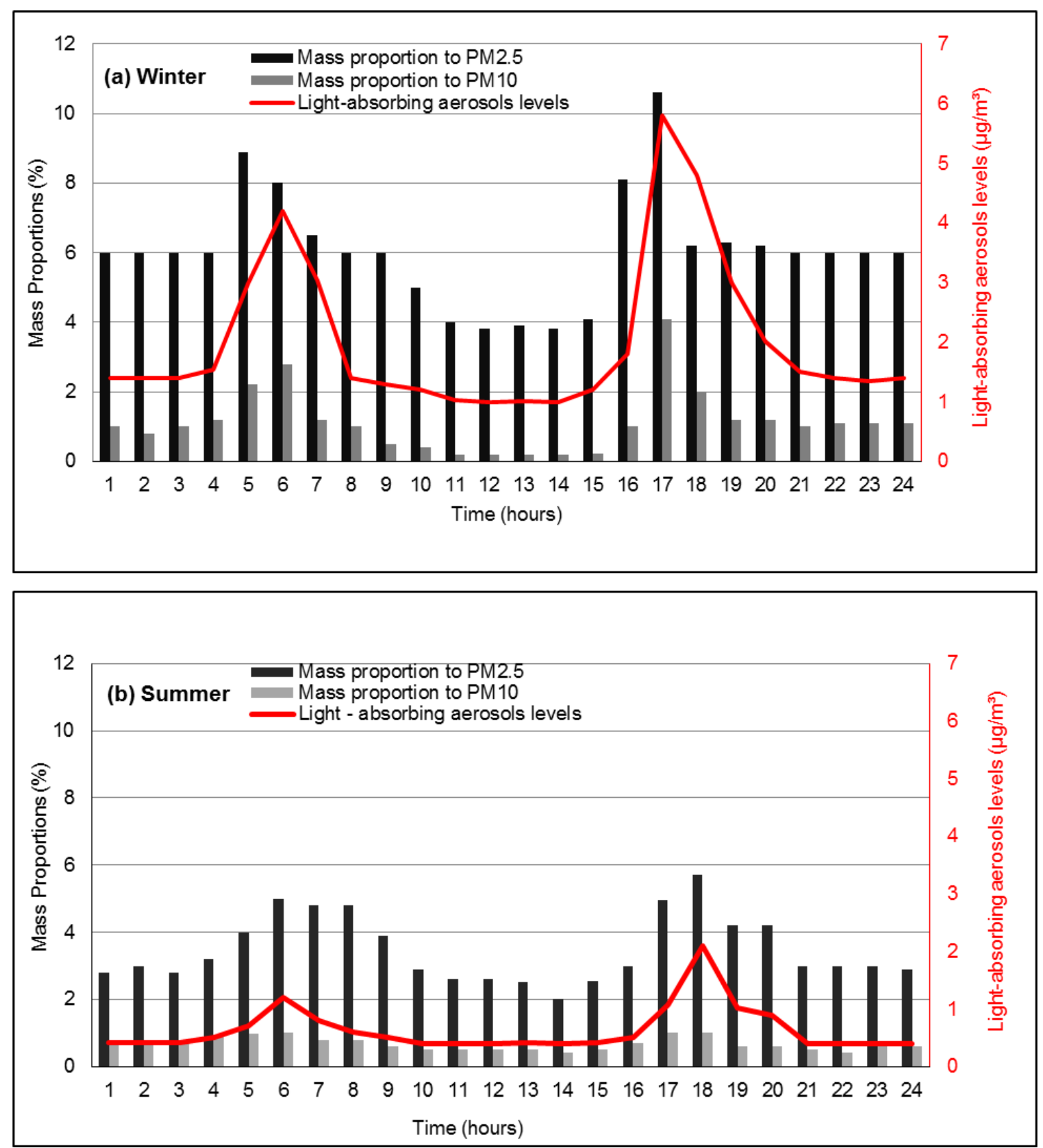

Fig. 4. Average diurnal mass concentrations of light-absorbing aerosols to total particulate matter measured in Kwadela Township during the winter 2014 and summer 2015 sampling periods.

Maximum one-hour $\mathrm{PM}_{2.5}$ levels in winter and summer were $61.31 \mu \mathrm{g} \mathrm{m}^{-3}$ and $34.69 \mu \mathrm{g} \mathrm{m}^{-3}$, respectively. In addition, $\mathrm{PM}_{10}$ had peak mass concentrations of $302.77 \mu \mathrm{g} \mathrm{m}^{-3}$ and $167.77 \mu \mathrm{g} \mathrm{m}^{-3}$ during winter and summer, respectively. Averages of light-absorbing aerosols were $6.5 \pm 1.0 \%$ and $3.4 \pm 1.0 \%$ of $\mathrm{PM}_{2.5}$ mass concentrations in winter and summer, respectively, and $<1 \pm 0.3 \%$ of $\mathrm{PM}_{10}$ (based on winter and summer five-minute averages) in both seasons.

Hourly averaged proportions of light-absorbing aerosols to $\mathrm{PM}_{2.5}$ show maxima of $8.9 \%$ and $10.6 \%$ in the morning and afternoon peak-hours, respectively, in winter (Fig. 4). Similar measurements were obtained in previous studies in Vaal Triangle Airshed Priority Area and the Highveld Priority Area (Diepkloof, Sebokeng, Sharpeville, Witbank,
Secunda, Three Rivers, Zamdela and Kliprivier) in South Africa (Feig et al., 2015). The diurnal cycle of the mass proportion corresponds with the diurnal cycle of the lightabsorbing aerosol mass concentrations (Fig. 3), with the highest peak observed in the afternoon. This correspondence implies that domestic solid-fuel combustion is one of the most important sources of $\mathrm{PM}_{2.5}$ light-absorbing aerosols during these peak times. A similar pattern was observed during summertime, where hourly averaged proportions of light-absorbing aerosols to $\mathrm{PM}_{2.5}$ peaked at $5 \%$ and $5.7 \%$ in the morning and afternoon peak hours, respectively (Fig. 4). The reduction in the relative importance of the solid fuel combustion may reflect the lower consumption of households of solid fuels during summer months. 
The diurnal patterns of the light-absorbing aerosol fractions to $\mathrm{PM}_{2.5}$ and $\mathrm{PM}_{10}$ levels were relatively higher in winter than in summer. Air pollution levels were higher in the morning and afternoons and minimal at midday in both seasons. Such aerosol temporal variability trends correspond with traffic as well as domestic fire patterns studied by Pauw et al., (2014) in Kwadela Township. Such high proportions of fine light-absorbing aerosols can be attributed to contributions from anthropogenic related primary sources such as domestic coal/wood combustion and diesel emissions in Kwadela Township (van der Berg et al., 2015). A study by Language et al. (2016) showed that solid fuels burnt in Kwadela can generate high mass concentrations of fine particulates $\left(\mathrm{PM}_{4}\right.$-particulate matter with aerodynamic diameter $\leq 4 \mu \mathrm{m}$ ). Domestic fuel combustion can contribute significant amounts of air particulates particularly in winter, where carbonaceous fuels are burnt for cooking and space heating (Lourens et al., 2011; Laakso et al., 2012).

\section{Comparison of Light-absorbing Aerosol Mass}

Concentration Fractions with Results from Other Regions

The proportion of light-absorbing aerosols to $\mathrm{PM}_{2.5}$ from various regions in South Africa (Amersfoort, Diepkloof, Sebokeng, Sharpeville, Witbank, Secunda, Three Rivers, Zamdela, Kliprivier) and internationally (Manyuki, Meru, Mukteshwar and Beijing) are summarised in Table 1. Many sites (Kliprivier, Amersfoort, Diepkloof, Sebokeng, Sharpeville, Secunda, Three Rivers, Zamdela and Witbank) have similar average mass concentrations of light-absorbing aerosols which range between $1.9 \mu \mathrm{g} \mathrm{m}^{-3}$ and $2.1 \mu \mathrm{g} \mathrm{m}^{-3}$, while Kwadela levels were $1.9 \pm 0.6 \mu \mathrm{g} \mathrm{m}^{-3}$ and $0.7 \pm 0.2 \mu \mathrm{g} \mathrm{m}^{-3}$ in winter and in summer, respectively (note that the measurements were taken with different instruments in all the sites). This indicates an average range of light-absorbing aerosols levels in multiple low-income settlements in South Africa, although some of these townships (e.g., Diepkloof and Three Rivers) are likely less dependent on solid fuel combustion for household energy.

The light-absorbing aerosol concentrations at many sites in South Africa are higher than levels measured in rural sites in Kenya shown in Table 1 (Gatari and Boman, 2003). Research indicates that light-absorbing particulate levels at the Kenyan site were strongly influenced by domestic solid fuel combustion (wood and coal). Such measurements suggest the importance of residential solid-fuel burning to mass loading light-absorbing particles mass loading.

\section{The Wavelength Dependence of the Light-absorption Coefficient}

Theoretically, BC is indicated by $\mathrm{AAE}=1(\mathrm{Wu}$ et al., 2009; Filep et al., 2013) with a potential range of 0.8 and 1.1 (Bergstrom et al., 2007; Gyawali et al., 2009). BrC is generally represented by AAE close to 2 at shortwavelengths (Gyawali et al., 2009; Lim et al., 2014; Dumka et al., 2018). AAE of 1-1.3 indicate the presence of fossil fuel related aerosols from traffic emissions, domestic/industrial fuel combustion. AAE of 1.8-3.5 suggest the contributions of light-absorbing particulates from wood and agricultural waste burning (Stockwell et al., 2016; Dumka et al., 2018;
Liakakou et al., 2020). AAE of 1.5 can be attributed to coal combustion aerosols, whereas particulates from chimney plumes and dust are indicated by an AAE of 1.4 and 1.8, respectively (Yang et al., 2009). Bond et al. (2002) measured AAE between 1.1 and 2.9 from low quality coal-combustion, which indicated the presence of $\mathrm{BC}$ and $\mathrm{BrC}$ in sampled air. Specifically, $\mathrm{AAE}=1.6$ suggest the co-existence of $\mathrm{BrC}$ and BC (Lee et al., 2012), associated with biofuel combustion (Sun et al., 2007). Generally, traffic related emissions mainly contain BC particulates, whereas biofuel burning can release significant proportions of both $\mathrm{BC}$ and $\mathrm{BrC}$ (Wan et al., 2017).

Winter hourly averaged $\mathrm{AAE}_{(370 / 880)}$ measured here ranged between 1.48 to 1.81 , with an average of $1.7 \pm 0.5$, indicative of a predominance of $\mathrm{BrC}$ possibly from biofuel burning sources such as wood and/biomass burning (Liakakou et al., 2020) and/or low-quality coal combustion (Bond et al., 2002) from residential cooking stoves (Stockwell et al., 2016). The minimum AAE values were observed at 07:00 $(\mathrm{AAE}=1.6)$ and 17:00 (AAE = 1.48), coinciding with the times when fossil fuel is in demand for cooking/and heating (Fig. 5).

In summer, hourly averaged $\mathrm{AAE}_{(370 / 950)}$ showed a strong bimodal cycle with distinct peaks in the morning and afternoon peak hours. AAE values were close to 1.5 at 6:00 and 17:00; and dropped to $\leq 1.1$ at midday (11:00-15:00) and late evening until early morning hours (20:00-4:00) (Fig. 5)

Hourly averaged AAE ranged between 0.8 and 1.1 at midday and overnight during summer, indicative the dominance of BC aerosols (Gyawali et al., 2009; Moosmüller et al., 2009) from diesel exhaust (Arnott et al., 2005; Moosmüller et al., 2009) because local solid-fuel burning is less prevalent at midday and overnight. Maximum AAE values were close to 1.6 in summer, indicating the co-existence of $\mathrm{BrC}$ and $\mathrm{BC}$ (Lee et al., 2012), from biofuel combustion (Sun et al., 2007).

On average, $\mathrm{BC}$ and $\mathrm{BrC}$ indicated by $\mathrm{AAE}$ average (1.3 \pm $0.7)$, dominated during summer sampling period. The estimated AAE average $(1.3 \pm 0.7)$ represents urban pollution (Backman et al., 2014); including biofuel-burning aerosols (Srivastava et al., 2012; Stockwell et al., 2016; Dumka et al., 2018; Liakakou et al., 2020). Favez et al. (2009) also found a similar AAE value (1.25) which was associated with domestic solid-fuel combustion particles.

AAE values were higher during winter (range: 1.48-1.81) compared to summer (range: 0.9-1.5) (Fig. 6), indicating a pronounced seasonality in the emission rates and the diversity of light-absorbing aerosol sources, as well as differences in mixing processes in the atmosphere (Srivastava et al., 2014; Stockwell et al., 2016). For example, BrC absorption can be reduced by $80 \%$ during the day due to photobleaching and the increasing of the boundary layer height (Satish et al., 2017).

The analysis of AAE is wavelength pair-specific (Favez et al., 2009; Dumka et al, 2018). For instance, AAE values measured at short wavelengths are relatively higher (AAE $>1.5$ ) than those measured at longer wavelengths (Fig. 7), indicating the significant contributions of $\mathrm{BrC}$ possibly from wood/biomass burning and agricultural waste. The organic 


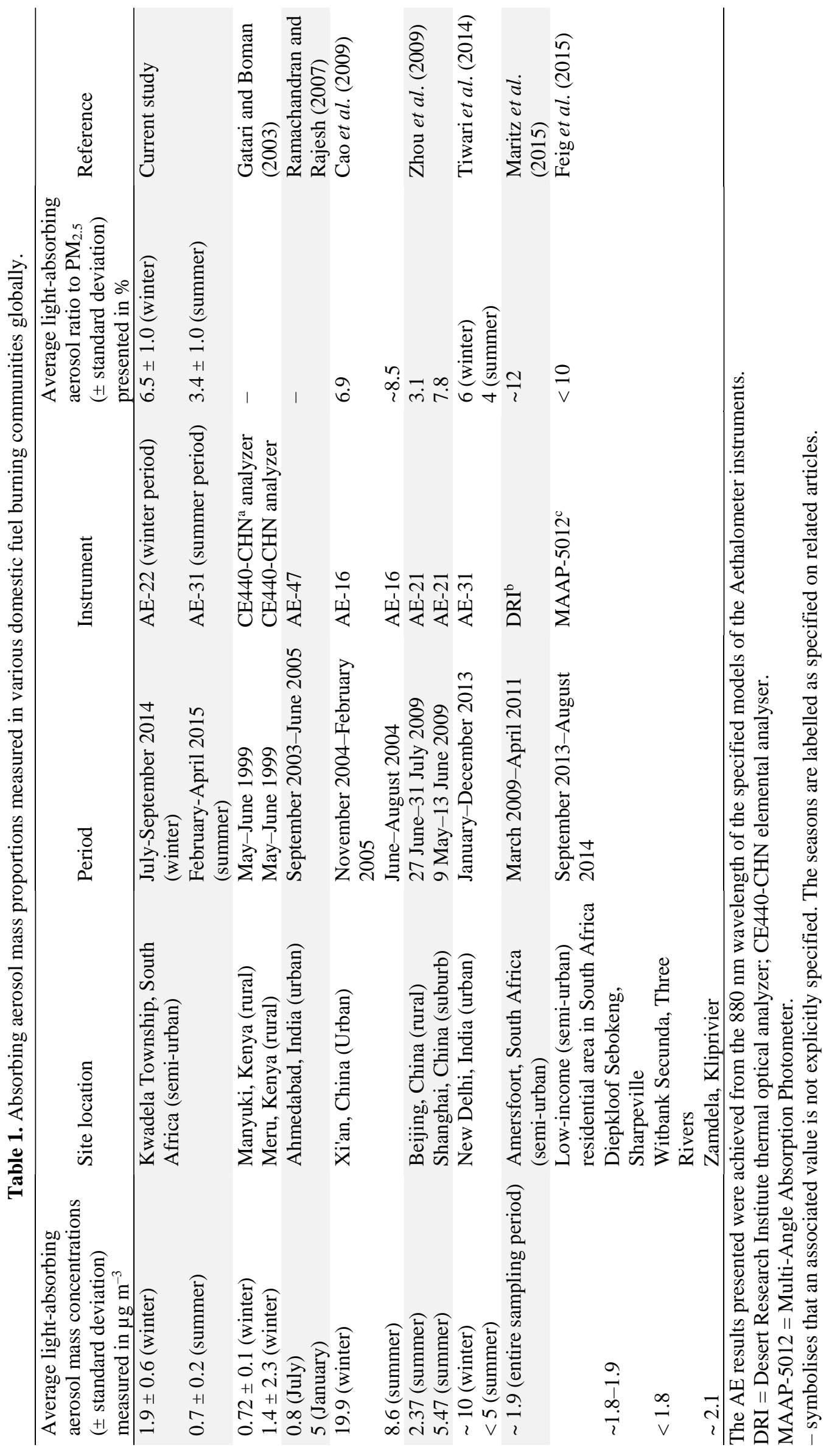




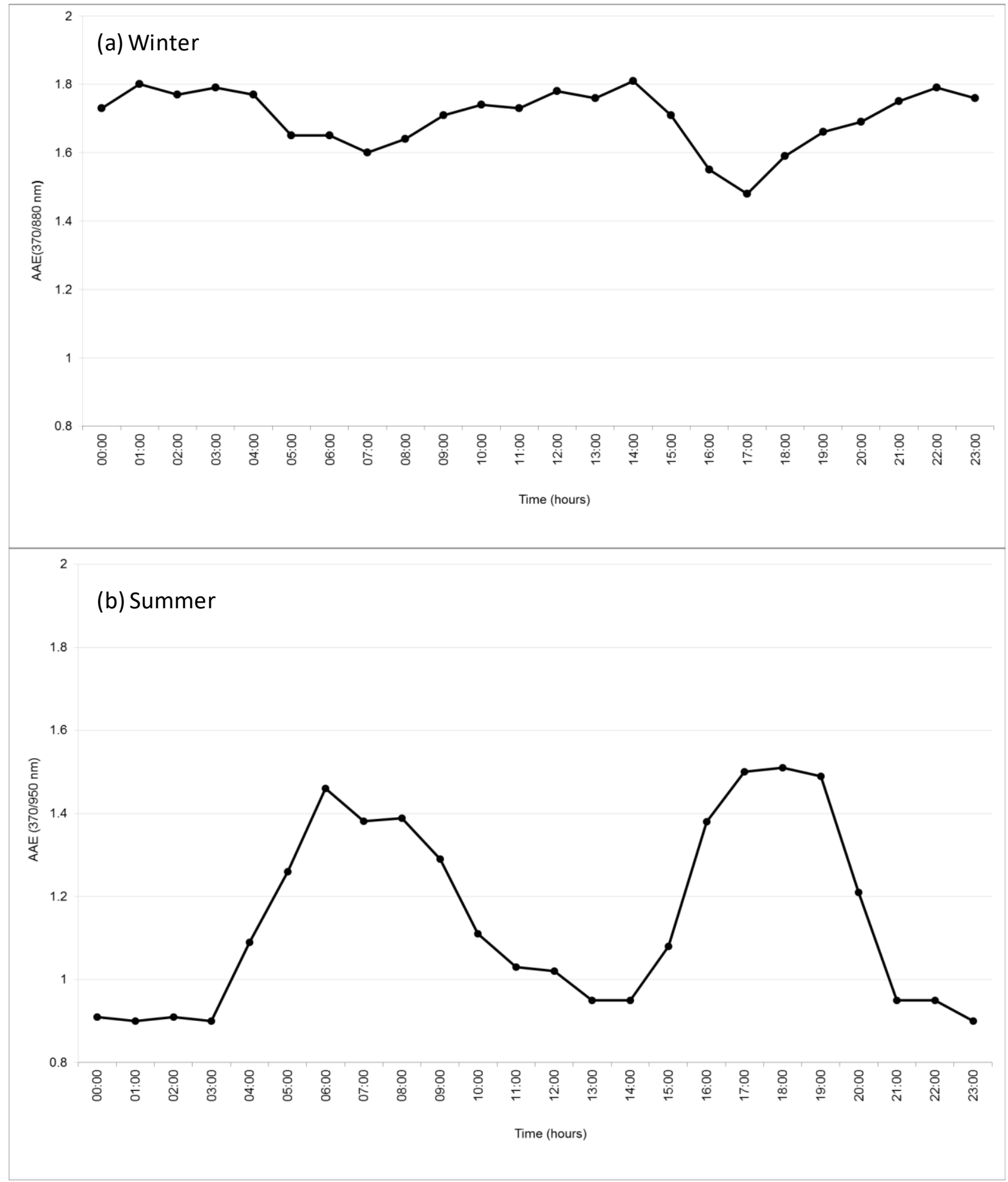

Fig. 5. Diurnal trends of the absorption Ångström exponent measured at 370/880 nm (winter) and 370/950 nm (summer) wavelength pair. The boxes represent mean values.

species that are released from biofuel combustion are more sensitive to short wavelengths compared to particulates that are emitted during fossil fuel burning (Zhang et al., 2017; Li et al., 2018). This is because AAE measured at short wavelengths is much more sensitive to $\mathrm{BrC}$ aerosols and internally mixed aerosols (Dumka et al., 2018; Liakakou et al., 2019). BrC has a highly wavelength-dependent imaginary refractive index, which is higher at shorter wavelengths relative to long wavelengths (Moosmüller et al., 2009; Chakrabarty et al., 2010).

AAE is also highly sensitive to fuel type, combustion efficiency and aging processes (Kirchstetter et al., 2004; Bond and Bergstrom, 2006), such that changes in the type of wood and the combustion conditions can affect the optical, physical and chemical aerosol properties (Day et al., 2006). Although fossil fuel and biomass burning are regarded as the 

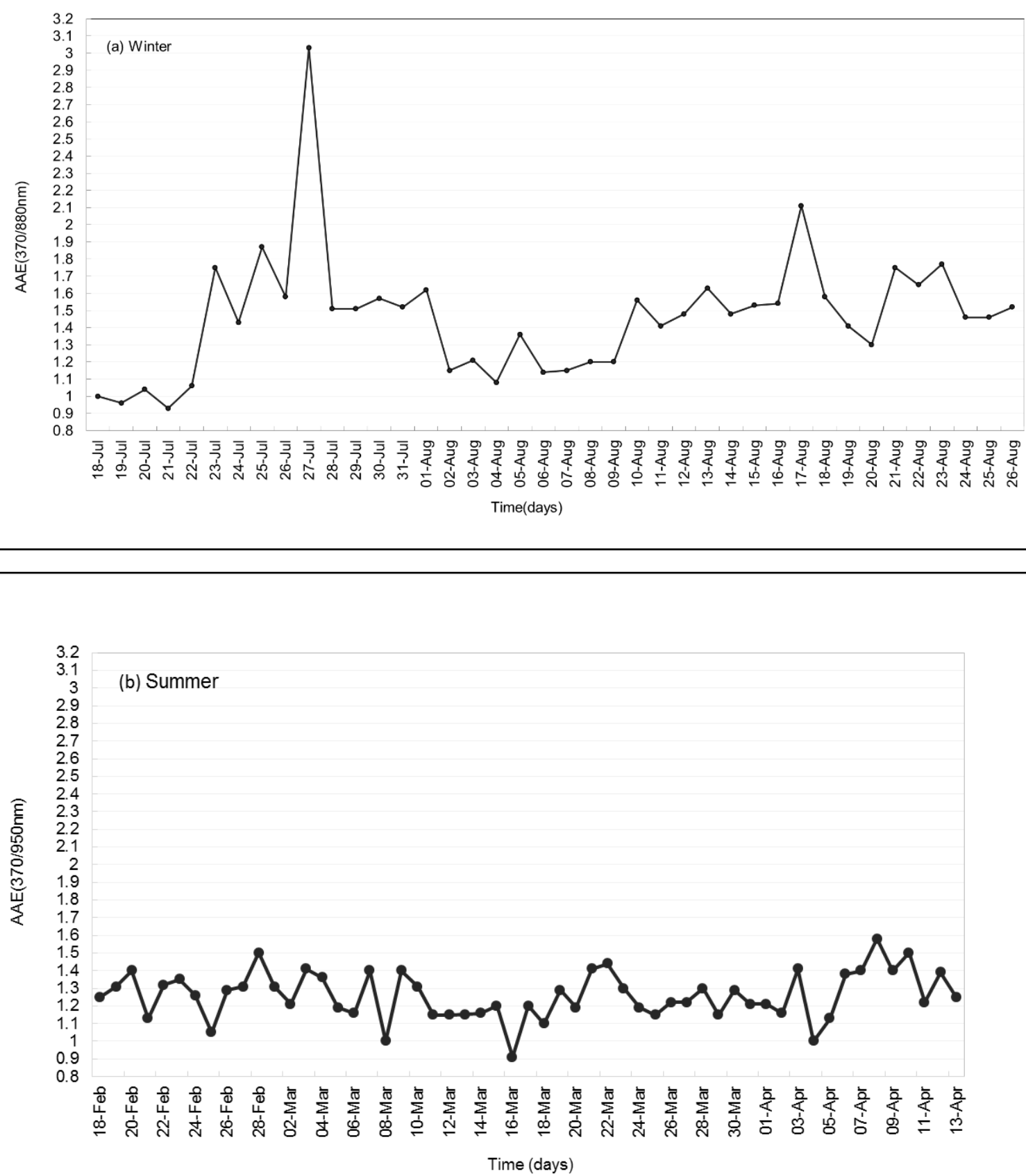

Fig. 6. Daily averaged AAE $(370 / 880 \mathrm{~nm})$ and AAE $_{(370 / 950 \mathrm{~nm})}$ measured in the winter (2014) and summer (2015) period, respectively. The solid circles represent mean values.

primary anthropogenic sources of light-absorbing aerosols, the aerosol absorbing properties of light-absorbing particles emitted from these sources may differ significantly. For instance, fossil-fuel generated BC has $100 \%$ more effective warming potential than that from biomass burning (Ramana et al., 2010). The difference in the warming potential of these aerosols is based on the ratio of $\mathrm{BC}$ to sulfate, with fossil-fuel combustion having a lower sulfate content compared with biomass burning (Ramana et al., 2010). Ramana et al.
(2010) found that the BC absorption efficiency was inversely proportional to the level of sulfate particles within the measured sample, having a relatively higher absorption efficiency corresponding with a lower sulfate level. This partly implies that domestic-fuel combustion can have remarkable implications on the regional solar radiation balance.

The AAE analysis can also be complicated by the aerosolmixing effect. A non-absorbing coating on a light-absorbing aerosol core can serve as a lens that focuses the incident light 


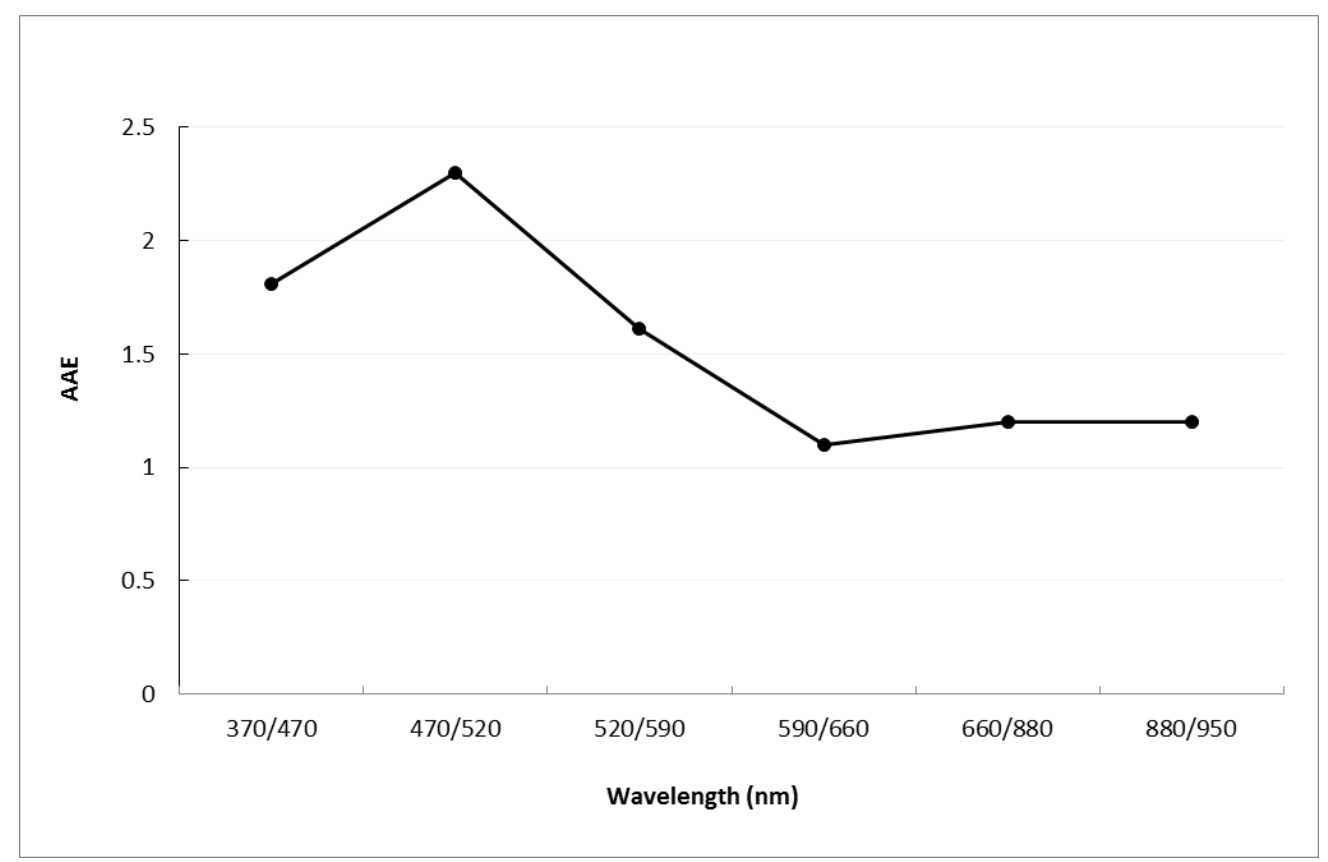

Fig. 7. Absorption Ångström exponent measured at different wavelength pairs during summer (2015). The solid circles represent mean values.

towards the light-absorbing aerosol core, thus increasing its absorption efficiency (Yang et al., 2009; Lee et al., 2012; Lim et al., 2014). Such an effect is common during hazy conditions and sulfate-rich pollution events (Chung et al., 2012; Schuster et al., 2016). This is due to the abundance of scattering material, such as secondary inorganic and organic aerosols, increasing the probability of internal mixing $(\mathrm{Wu}$ et al., 2009). BC internally mixed with non-absorbing material is indicated by $\mathrm{AAE}=1.5$ (Bond and Bergstrom, 2006) or 1.6 (Lack and Langridge, 2013). Therefore, the strong bimodal pattern observed during summer (Fig. 5) may suggest the dominance of internally mixed BC during peak hours, possibly from combustion of carbonaceous fuels (Lelieveld et al., 2015). The combustion of solid fuels can emit both $\mathrm{BC}$ and organic and/ inorganic gases that can form secondary aerosols (Mugabo, 2011). The peak AAE value of 1.5 (as observed in Fig. 5), particularly indicates the presence of coal-derived internally mixed BC particulates (Yang et al., 2009). For the current study, aerosol mixing is possible as measurements were not taken directly from the source (stove chimney), but rather from mixed ambient air, which is subject to continuous atmospheric processing and thus changes in chemical composition, which can strongly affect AAE values (Saleh et al., 2014; Costabile et al., 2017). AAE values are indicative of variations of aerosol chemical composition and their source types (Dumka et al., 2018)

On average, a mixture of internally mixed BC particles and $\mathrm{BrC}$ particles (indicated by an $\mathrm{AAE} \geq 1.5$ ) (Yang et al., 2009; Bond and Bergstrom, 2006; Lack and Langridge, 2013) dominated on 50\% and 5\% of the winter (2014) and summer (2015) sampling days, respectively. Relatively fresh $\mathrm{BC}$ particles (suggested by an $\mathrm{AAE} \leq 1.1$ ) (Gyawali et al., 2009; Bond et al., 2013; Filep et al., 2013) were only measured during summer days (23\%) (Fig. 6).
Internally mixed $\mathrm{BC}$ aerosols have increased absorption efficiency (Chung et al., 2012; Lee et al., 2012; Wu et al., $2015)$ that can be a factor of 1.9 higher than non-coated BC (Chung et al., 2012). Manoharan et al. (2014) found that coated BC particles have $30 \%$ higher absorption potential and $44 \%$ regional radiative forcing compared with pure BC particles. These effects can also be applicable in Kwadela settlement since coated $\mathrm{BC}$ particles are estimated to dominate during the day (see Fig. 5, cases when AAE $\geq 1.5$ ) when solar irradiance is higher and these peaks are observed in most of the days (Fig. 6). Relatively high BC loading (particularly during peak hours), coupled with intense lightabsorption due to aerosol mixing can lead to an increase in temperatures (Moosmüller et al., 2009; Wu et al., 2009). Thus, residential solid-fuel and biomass combustion is an important source of light-absorbing aerosols in this study region, which can be associated with human health and environmental impacts. The usage of relatively cleaner fuels such as natural gas or electricity can improve air quality, and thus reduce human health and environmental impacts.

\section{CONCLUSIONS}

Light-absorbing aerosol mass concentrations measured at Kwadela low-income settlement were higher in the 2014 winter relative to the 2015 summer $\left(0.66 \pm 0.2 \mu \mathrm{g} \mathrm{m}^{-3}\right)$. Hourly averaged levels show distinct peaks in the early mornings (4.2 and $1.2 \mu \mathrm{g} \mathrm{m}^{-3}$ ) and early evenings (5.8 and $2.1 \mu \mathrm{g} \mathrm{m}^{-3}$ ) during winter and summer, respectively. There were minimum ambient mass concentrations at midday when wind speed and boundary layer heights are higher, thus facilitating pollution dissipation. This is also typically the time of the day when emissions from domestic combustion are lowest. Higher concentrations were obtained during the 
times when the use of solid fuel is more prevalent, namely in the morning (6:00) and in the evenings (17:00) in winter. During summer, the peaks occurred between at 6:00 and 18:00 in the morning and evening, correspondingly. Low light-absorbing aerosol levels at mid-day may also be attributed to the chemical transformation of light-absorbing aerosols less absorbing secondary particulates.

Higher proportions of absorbing aerosols to total $\mathrm{PM}_{2.5}$ were observed in winter (6.5\%) and during two peak burning hours $(10.6 \%$ and $5.7 \%)$ in winter and summer, respectively. There were low proportions $(<1 \pm 0.3 \%)$ of absorbing aerosols to $\mathrm{PM}_{10}$ in both sampling seasons. Hourly averaged aerosol absorption mass concentrations proportional to $\mathrm{PM}_{2.5}$ and $\mathrm{PM}_{10}$ particulate matter mass concentrations had a distinct bimodal diurnal cycle in winter and summer.

Kwadela low-income settlement absorbing aerosol levels were similar to those measured in other South African lowincome settlement studies; with mass concentrations ranging from 1.9 to 2.1 and proportions of light-absorbing aerosols to $\mathrm{PM}_{2.5}$ close to $10 \%$ in the South African Vaal Triangle Airshed Priority Area and the Highveld Priority Area. The results from these reviewed previous studies indicate average levels of light-absorbing aerosol in residential areas, which are influenced by local fuel combustion. The presence of $\mathrm{BC}$ and $\mathrm{BrC}$ was suggested by the $\mathrm{AAE}_{(370 / 880 \mathrm{~nm})}$ during winter 2014 and summer (AAE $370 / 950 \mathrm{~nm}) 2015$ campaign. The average AAE values, which ranged between 0.9 and 1.5, indicated the dominance of internally mixed BC during the morning and afternoon peaks which, in the low-income settlements of the Highveld, are associated with domestic solid-fuel combustion. Relatively fresh BC particles were only measured during summer days $(23 \%)$. These proportions suggest the important contributions of light-absorbing aerosols from biomass/wood burning in winter and fossil fuel combustion in summer.

Winter AAE values were higher relative to summer AAE values, indicating a pronounced seasonality in the emission rates and the diversity of combustion sources between biofuels/biomass burning and/or coal combustion emissions (in winter) and fossil fuel combustion (in summer), as well as differences in mixing processes in the atmosphere.

The results from this study indicate that residential solidfuel and/biofuel combustion has an important influence on characterization of light-absorbing aerosols and thus can have human health and environmental importance. This information will be useful for improvement of the assessment of human health and environmental impacts, as well as air-quality management. It is well recognized that high levels of aerosols can affect human health and the environment negatively. Understanding the extent of such effects can be incomplete without full knowledge of all the existing aerosol types, particularly since light-absorbing particles are the least studied on a regional scale. Moreover, this research will raise awareness about the influence of domestic fuel energy usage on the light-absorbing aerosol mass loading in low-income settlements, which can assist with air-quality management. Further studies should focus on the health implications in the South African context of BC aerosols.

In terms of consistency of the findings of the current research with literature, this study provides new insight on the light-absorption characteristics of $\mathrm{BC}$ and $\mathrm{BrC}$, associated with burning of the low-quality coal and biofuels in South Africa. This study also highlights the importance of domestic solid fuel combustion as a source of $\mathrm{BrC}$ in addition to biomass burning emission in residential areas. The diurnal dynamic changes of aerosol light-absorption characteristics are also remarkable particularly during the summer season, which is associated with long-lasting high-pressure systems over the research area. The analysed ground-based data highlight pronounced seasonality in the emission rates and the diversity of combustion sources between biomass/biofuel burning (in winter) and fossil fuel combustion (summer), which contribute significant proportions of carbonaceous particles in a low-income settlement of southern Africa.

\section{ACKNOWLEDGEMENTS}

The authors would like to thank the National Research Fund (NRF), SASOL South Africa (Pty) Ltd. and the National Association for Clean Air (NACA) for funding. The Council for Scientific and Industrial Research (CSIR) provided financial support to Dr. Garland (Parliamentary Grant). This work is based on the research supported in part by the NRF(CSUR) (Grant Number: 9157) to Dr. Rebecca M. Garland. Special thanks to the South African Weather Service (SAWS) for the provision of the Aethalometer AE-22 and MAAP-5012 instruments.

\section{SUPPLEMENTARY MATERIAL}

Supplementary data associated with this article can be found in the online version at https://aaqr.org/

\section{REFERENCES}

Arnott, W.P., Hamasha, K., Moosmüller, H., Sheridan, P.J. and Ogren, J.A. (2005). Towards aerosol light absorption measurements with a 7-wavelength aethalometer: Evaluation with a photoacoustic instrument and 3wavelength nephelometer. Aerosol Sci. Technol. 39: 1729. https://doi.org/10.1080/027868290901972

Backman, J., Virkkula, A., Vakkari, V., Beukes, J.P., van Zyl, P.G., Josipovic, M., Piketh, S., Tiitta, P., Chiloane, K., Petäjä, T., Kulmala, M. and Laakso, L. (2014). Differences in aerosol absorption Ångström exponents between correction algorithms for particle soot absorption photometer measured on the South African Highveld. Atmos. Meas. Tech. 7: 4285-4298. https://doi.org/10.5194/ amt-7-4285-2014

Badarinath, K.V.S., Sharma, A.R., Kaskaoutis, D.G., Kharol, S.K. and Kambezidis, H.D. (2010). Solar dimming over the tropical urban region of Hyderabad, India: Effect of increased cloudiness and increased anthropogenic aerosols. J. Geophys. Res. 115: D21208. https://doi.org/1 0.1029/2009JD013694

Bergstrom, R.W., Pilewskie, P., Russell, P.B., Redemann, J., Bond, T.C., Quinn, P.K. and Sierau, B. (2007). Spectral absorption properties of atmospheric aerosols. Atmos. 
Chem. Phys. 7: 5937-5943. https://doi.org/10.5194/acp7-5937-2007

Bond, T.C., Covert, D.S., Kramlich, J.C., Larson, T.V. and Charlson, R.J. (2002). Primary particle emissions from residential coal burning: Optical properties and size distributions. J. Geophys. Res. 107: 8347. https://doi.org/ 10.1029/2001JD000571

Bond, T.C. and Bergstrom, R.W. (2006). Light absorption by carbonaceous particles: An investigative review. Aerosol Sci. Technol. 40: 27-67. https://doi.org/10.1080/ 02786820500421521

Bond, T.C., Doherty, S.J., Fahey, D.W., Forster, P.M., Berntsen, T., DeAngelo, B.J., Flanner, M.G., Ghan, S., Kärcher, B., Koch, D., Kinne, S., Kondo, Y., Quinn, P.K., Sarofim, M.C., Schultz, M.G., Schulz, M., Venkataraman, C., Zhang, H., Zhang, S., ... Zender, C.Z. (2013). Bounding the role of black carbon in the climate system: A scientific assessment. J. Geophys. Res. 118: 5380-5552 https://doi.org/10.1002/jgrd.50171

Butt, E.W., Rap, A., Schmidt, A., Scott, C.E., Pringle, K.J., Reddington, C.L., Richards, N.A., Woodhouse, M.T., Ramirez-Villegas, J., Yang, H., Vakkari, V., Stone, E.A., Rupakheti, M., Praveen, P.S., van Zyl, P.G., Beukes, J.P., Josipovic, M., Mitchell, E.J., Sallu, S.M., ... Spracklen, D.V. (2015). The impact of residential combustion emissions on atmospheric aerosol, human health and climate. Atmos. Chem. Phys. 16: 873-905. https://doi.org/ 10.5194/acp-16-873-2016

Cao, J.J., Zhu, C.S., Chow, J.C., Watson, J.G., Han, Y.M., Wang, G.H., Shen, Z.X. and An, Z.S. (2009). Black carbon relationships with emissions and meteorology in Xi'an, China. Atmos. Res. 94: 194-202. https://doi.org/10. 1016/j.atmosres.2009.05.009

Cappa, C.D., Lack, D.A., Burkholder, J.B. and Ravishankara, A.R. (2008). Bias in filter-based aerosol light absorption measurements due to organic aerosol loading evidence from laboratory measurements. Aerosol Sci. Technol. 42: 1022-1032. https://doi.org/10.1080/02786820802389285

Cazorla, A., Bahadur, R., Suski, K.J., Cahill, J.F., Chand, D., Schmid, B., Ramanathan, V. and Prather, K.A. (2013). Relating aerosol absorption due to soot, organic carbon, and dust to emission sources determined from in-situ chemical measurements. Atmos. Chem. Phys. 13: 93379350. https://doi.org/10.5194/acp-13-9337-2013

Chakrabarty, R.K., Moosmüller, H., Chen, L.W.A., Lewis, K., Arnott, W.P., Mazzoleni, C., Dubey, M.K., Wold, C.E., Hao, W.M. and Kreidenweis, S.M. (2010). Brown carbon in tar balls from smoldering biomass combustion. Atmos. Chem. Phys. 10: 6363-6370. https://doi.org/10.51 94/acp-10-6363-2010

Chiloane, K.E., Beukes, J.P., van Zyl, P.G., Maritz, P., Vakkari, V., Josipovic, M., Venter, A.D., Jaars, K., Tiitta, P., Kulmala, M., Wiedensohler, A., Liousse, C., Mkhatshwa, G.V., Ramandh, A. and Laakso, L. (2017). Spatial, temporal and source contribution assessments of black carbon over the northern interior of South Africa. Atmos. Chem. Phys. 17: 6177-6196. https://doi.org/10.51 94/acp-17-6177-2017

Chung, C.E., Ramanathan, V. and Decremer, D. (2012).
Observationally constrained estimates of carbonaceous aerosol radiative forcing. PNAS 109: 11624-11629. https://doi.org/10.1073/pnas.1203707109

Costabile, F., Gilardoni, S., Barnaba, F., Di Ianni, A., Di Liberto, L., Dionisi, D., Manigrasso, M., Paglione, M., Poluzzi, V., Rinaldi, M., Facchini, M.C. and Gobbi, G.P. (2017). Characteristics of brown carbon in the urban Po Valley atmosphere. Atmos. Chem. Phys. 17: 313-326. https://doi.org/10.5194/acp-17-313-2017

Day, D.E., Hand, J.L., Carrico, C.M., Engling, G. and Malm, W.C. (2006). Humidification factors from laboratory studies of fresh smoke from biomass fuels. J. Geophys. Res. 111: D22202. https://doi.org/10.1029/2006JD007221

Dumka, U.C., Kaskaoutis, D.G., Srivastava, M.K. and Devara, P.C. (2015). Scattering and absorption properties of nearsurface aerosol over Gangetic-Himalayan region: The role of boundary-layer dynamics and long-range transport. Atmos. Chem. Phys. 15: 1555-1572. https://doi.org/10.519 4/acp-15-1555-2015

Dumka, U.C., Kaskaoutis, D.G., Tiwari, S., Safai, P.D., Attri, S.D., Soni, V.K., Singh, N. and Mihalopoulos, N. (2018). Assessment of biomass burning and fossil fuel contribution to black carbon concentrations in Delhi during winter. Atmos. Environ. 194: 93-109. https://doi.org/10.10 16/j.atmosenv.2018.09.033

Dumka, U.C., Kaskaoutis, D.G., Devara, P.C.S., Kumar, R., Kumar, S., Tiwari, S., Gerasopoulos, E. and Mihalopoulos, N. (2019). Year-long variability of the fossil fuel and wood burning black carbon components at a rural site in southern Delhi outskirts. Atmos. Res. 216: 11-25. https://doi.org/10.1016/j.atmosres.2018.09.016

Engelbrecht, J.P., Swanepoel, L., Chow, J.C., Watson, J.G. and Egami, R.T. (2001). $\mathrm{PM}_{2.5}$ and $\mathrm{PM}_{10}$ concentrations from the Qalabotjha low-smoke fuels macro-scale experiment in South Africa. Environ. Monit. Assess. 69: 1-15. https://doi.org/10.1023/A:1010786615180

Favez, O., Cachier, H., Sciare, J., Sarda-Estève, R. and Martinon, L. (2009). Evidence for a significant contribution of wood burning aerosols to $\mathrm{PM}_{2.5}$ during the winter season in Paris, France. Atmos. Environ. 43: 3640 3644. https://doi.org/10.1016/j.atmosenv.2009.04.035

Favez, O., El-Haddad, I., Piot, C., Boréave, A., Abidi, E., Marchand, N., Jaffrezo, J.L., Besombes, J.L., Personnaz, M.B., Sciare, J., Wortham, H., George, C. and D'Anna,B. (2010). Inter-comparison of source apportionment models for the estimation of wood burning aerosols during wintertime in an Alpine city (Grenoble, France). Atmos. Chem. Phys. 10: 5295-5314. https://doi.org/10.5194/acp10-5295-2010

Feig, G.T., Vertue, B., Naidoo, S., Ncgukana, N. and Mabaso, D. (2015). Measurement of atmospheric black carbon in the Vaal Triangle and Highveld Priority Areas. Clean Air J. 25: 46-50. https://doi.org/10.17159/2410972X/2015/v25n1a4

Feig, G., Ncipha, X., Vertue, B., Naidoo, S., Mabaso, D., Ngcukana, N., Tshehla, C. and Masuku, N. (2014). Analysis of a period of elevated ozone concentration reported over the Vaal Triangle on 2 June 2013. Clean Air J. 24: 10-16. https://doi.org/10.17159/caj/2014/24/1.7051 
Feig, G.T., Garland, R.M., Naidoo, S., Maluleke, A. and van der Merwe, M. (2019). Assessment of changes in concentrations of selected criteria pollutants in the Vaal and Highveld priority areas. Clean Air J. 29. https://www.cleanairjournal.org.za/article/view/7464

Filep, Á.F., Ajtai, T., Utry, N., Pintér, M.D., Nyilas, T., Takács, S., Máté, Z., Gelencsér, A., Hoffer, A., Schnaiter, M., Bozóki, Z. and Szabó, G. (2013). Absorption spectrum of ambient aerosol and its correlation with size distribution in specific atmospheric conditions after a red mud accident. Aerosol Air Qual. Res. 13: 49-59. https://doi.org/10.4209/aaqr.2012.04.0078

Freiman, M.T. and Piketh, S.J. (2003). Air transport into and out of the Industrial Highveld Region of South Africa. $J$. Appl. Meteorol. 42: 994-1002. https://doi.org/10.1175/15 20-0450(2003)042<0994:ATIAOO>2.0.CO;2

Friedl, A., Holm, D., John, J., Kornelius, G., Pauw, C.J., Oosthuizen, R. and van Niekerk, A.S. (2008). Air pollution in dense, low-income settlements in South Africa. Proceedings of the National Association for Clean Air (NACA) Conference, 2008, Nelspruit, Mpumalanga.

Gatari, M.J. and Boman, J. (2003). Black carbon and total carbon measurements at urban and rural sites in Kenya, East Africa. Atmos. Environ. 37: 1149-1154. https://doi.org/10.1016/S1352-2310(02)01001-4

Gierens, R. (2015). Understanding the evolution of the boundary layer over the Highveld, Msc. Thesis, University of Helsinki, South Africa. http://urn.fi/URN:NBN:fife2017112252423

Gyawali, M., Arnott, W.P., Lewis, K. and Moosmüller, H. (2009). In situ aerosol optics in Reno, NV, USA during and after the summer 2008 California wildfires and the influence of absorbing and non-absorbing organic coatings on spectral light absorption. Atmos. Chem. Phys. 9: 8007-8015. https://doi.org/10.5194/acp-9-8007-2009

Hansen, A.D.A. (2005). The Aethalometer ${ }^{\mathrm{TM}}$. Magee Scientific Company, Berkeley, CA, USA.

Hersey, S., Garland, R., Crosbie, E., Shingler, T., Sorooshian, A., Piketh, S. and Burger, R. (2015). An overview of regional and local characteristics of aerosols in South Africa using satellite, ground, and modeling data. Atmos. Chem. Phys. 15: 4259-4278. https://doi.org/10.5194/acp15-4259-2015

International Agency for Research on Cancer (IARC) (2012). IARC: Diesel engine exhaust carcinogenic. https://www.iarc.fr/news-events/iarc-diesel-engine-exhaustcarcinogenic/

Kambezidis, H.D., Kaskaoutis, D.G., Kharol, S.K., Moorthy, K.K., Satheesh, S.K., Kalapureddy M.C.R., Badarinath, K.V.S., Sharma, A.R. and Wild, M. (2012). Multi-decadal variation of the net downward shortwave radiation over south Asia: The solar dimming effect. Atmos. Environ. 50: 360-372. https://doi.org/10.1016/j.atmosenv.2011.11.008

Kaskaoutis, D.G., Kambezidis, H.D., Hatzianastassiou, N., Kosmopoulos, P.G. and Badarinath, K.V.S. (2007). Aerosol climatology: On the discrimination of aerosol types over four AERONET sites. Atmos. Chem. Phys. Discuss. 7: 6357-6411. https://doi.org/10.5194/acpd-76357-2007
Khumalo, T.N. (2017). 2017 state of air report and national air quality indicator. $12^{\text {th }}$ Air Quality Governance Lekgotla. Cedar Woods-Sandton, Gauteng Province, South African.

Koch, D. and Del-Genio, A.D. (2010). Black carbon semidirect effects on cloud cover: Review and synthesis. Atmos. Chem. Phys. 10: 7685-7696. https://doi.org/10.5194/acp10-7685-2010

Kuik, F., Lauer, A., Beukes, J.P., van Zyl, P.G., Josipovic, M., Vakkari, V., Laakso, L. and Feig, G.T. (2015). The anthropogenic contribution to atmospheric black carbon concentrations in southern Africa: A WRF-Chem modeling study. Atmos. Chem. Phys. 15: 8809-8830. https://doi.org/ 10.5194/acp-15-8809-2015

Laakso, L., Vakkari. V., Virkkula, A., Laakso, H., Backman, J., Kulmala, M., Beukes, J.P., van Zyl, P.G., Tiitta, P., Josipovic, M., Pienaar, J.J., Chiloane, K., Gilardoni, S., Vignati, E., Wiedensohler, A., Tuch, T., Birmili, W., Piketh, S., Collett, K., ... Kerminen,V.M. (2012). South African EUCAARI measurements: Seasonal variation of trace gases and aerosol optical properties. Atmos. Chem. Phys. 12: 1847-1864. https://doi.org/10.5194/acp-121847-2012

Lack, D.A. and Langridge, J.M. (2013). On the attribution of black and brown carbon light absorption using the Ångström exponent. Atmos. Chem. Phys. 13: 1053510543. https://doi.org/10.5194/acp-13-10535-2013

Language, B., Piketh, S.J., Wernecke, B. and Burger, R. (2016). Household air pollution in South African lowincome settlements: A case study, WIT Trans. Ecol. Environ. 207: 227-236. https://doi.org/10.2495/AIR160211

Lee, S., Yoon, S.C., Kim, S.W., Kim, Y.P., Ghim, Y.S., Kim, J.H., Kang, C.H., Kim, Y.J., Chang, L.S. and Lee, S.J. (2012). Spectral dependency of light scattering absorption and hygroscopicity of pollution and dust aerosols in Northeast Asia. Atmos. Environ. 50: 246-254. https://doi.org/10.1016/j.atmosenv.2011.12.026

Lelieveld, J., Evans, J.S., Fnais, M., Giannadaki, D. and Pozzer, A. (2015). The contribution of outdoor air pollution sources to premature mortality on a global scale. Nature 525: 367-371. https://doi.org/10.1038/nature15371

Li, S., Zhu, M., Yang, W., Tang, M., Huang, X., Yu, Y., Fang, H., Yu, X., Yu, Q., Fu, X., Song, W., Zhang, Y., Bi, X. and Wang, X. (2018). Filter-based measurement of light-absorption by brown carbon in $\mathrm{PM}_{2.5}$ in a megacity in South China. Sci. Total Environ. 633: 1360-1369. https://doi.org/10.1016/j.scitotenv.2018.03.235

Liakakou, E., Kaskaoutis, D.G., Grivas, G., Stavroulas, I., Tsagkaraki, M., Paraskevopoulou, D., Bougiatioti, A., Dumka, U.C., Gerasopoulos, E. and Mihalopoulos, N. (2020). Long-term brown carbon spectral characteristics in a Mediterranean city (Athens). Sci. Total. Environ. 708: 135019. https://doi.org/10.1016/j.scitotenv.2019.135019

Lim, S., Lee, M., Kim, S.W., Yoon, S.C., Lee, G. and Lee, Y.J. (2014). Absorption and scattering properties of organic carbon versus sulfate dominant aerosols at Gosan climate observatory in Northeast Asia. Atmos. Chem. Phys. 14: 7781-7793. https://doi.org/10.5194/acp-14-7781-2014 Lourens, A.S., Beukes, J. P., Van Zyl, P. G., Fourie, G.D., 
Burger, J.W., Pienaar, J. J., Read, C. E. and Jordaan, J.H. (2011). Spatial and temporal assessment of gaseous pollutants in the Highveld of South Africa. S. Afr. J. Sci. 107: 1-8. https://doi.org/10.4102/sajs.v107i1/2.269

Madhavan, B.L. (2008). Aerosol physico-chemical characterization during Indian summer monsoonImplications to radiative forcing. Dissertation- $\mathrm{PhD}$. Andhra University, Visakhapatnam.

Makonese, T., Forbes, P., Mudau, L. and Annegarn, H.J. (2014). Aerosol particle morphology of residential coal combustion smoke. Clean Air J. 24: 24-28. https://doi.org/ 10.17159/caj/2014/24/2.7064

Manoharan, V.S., Kotamarthi, R., Feng, Y. and Cadeddu, M.P. (2014). Increased absorption by coarse aerosol particles over the Gangetic-Himalayan region. Atmos. Chem. Phys. 14:1159-1165. https://doi.org/10.5194/acp14-1159-2014

Maritz, P. (2019). Long-term assessment of aerosol chemical composition in the interior of South Africa, Thesis-PhD, North West University, Potchefstroom. https://repository.nwu.ac.za/handle/10394/32805

Maritz, P., Beukes, J.P., van Zyl, P.G., Conradie, E.H., Liousse, C., Galy-Lacaux, C., Castéra, P., Ramandh, A., Mkhatshwa, G., Venter, A.D. and Pienaar, J.J. (2015). Spatial and temporal assessment of organic and black carbon at four sites in the interior of South Africa. Clean Air J. 25: 20-33. https://doi.org/10.17159/2410-972X/20 $15 / \mathrm{v} 25 \mathrm{n} 1 \mathrm{a} 1$

Massabò, D., Caponi, L., Bernardoni, V., Bove, M.C., Brotto, P., Calzolai, G., Cassola, F., Chiari, M., Fedi, M.E., Fermo, P., Giannoni, M., Lucarelli, F., Nava, S., Piazzalunga, A., Valli, G., Vecchi, R. and Prati, P. (2015). Multiwavelength optical determination of black and brown carbon in atmospheric aerosols. Atmos. Environ. 108: 112. https://doi.org/10.1016/j.atmosenv.2015.02.058

Mdluli, T.N. (2007). The societal dimensions of domestic coal combustion: People's perceptions and indoor aerosol monitoring. Thesis-PhD, University of the Witwatersrand, Johannesburg. https://core.ac.uk/reader/39665490

Moorthy, K.K., Babu, S.S. and Satheesh, S.K. (2007). Temporal heterogeneity in aerosol characteristics and the resulting radiative impact at a tropical coastal station-Part 1: Microphysical and optical properties. Ann. Geophys. 25: 2293-2308. https://doi.org/10.5194/angeo-25-2293-2007

Moosmüller, H., Chakrabarty, R.K. and Arnott, W.P. (2009) Aerosol light absorption and its measurement: A review. J. Quant. Spectrosc. Radiat. Transfer. 110: 844-878. https://doi.org/10.1016/j.jqsrt.2009.02.035

Mugabo, C. (2011). Ambient air quality in a low income urban area on the South African Highveld: A case study of Leandra Township. Msc. Dissertation, University of the Witwatersrand, Johannesburg. http://hdl.handle.net/1 0539/10003

Mukherjee, A., Stanton, L.G., Graham, A.R. and Roberts P.T. (2017). Assessing the utility of low-cost particulate matter sensors over a 12-week period in the Cuyama Valley of California. Sensors 17: 1805-1820. https://doi.org/10. 3390/s17081805

Naidoo, S., Piketh, S.J. and Curtis, C. (2014). Quantification of emissions generated from domestic burning activities from townships in Johannesburg. Clean Air J. 24: 34-41. https://doi.org/10.17159/caj/2014/24/1.7047

Nkosi, N.C., Piketh, S.J. and Burger, R.P. (2018). Fine PM emission factors from residential burning of solid fuels using traditional cast-iron coal stoves. Clean Air J. 28: 3541. https://doi.org/10.17159/2410-972x/2018/v28n1a10

Pauw, C.J., Piketh, S.J., Burger, R.P. and Grove, C. (2014). The temporal profile of solid fuel indoor temperature and personal exposure to air pollution in a Highveld township (poster). $30^{\text {th }}$ annual conference of South African Society for Atmospheric Sciences (SASAS), Potchefstroom, South Africa.

Petzold, A., Ogren, J.A., Fiebig, M., Laj P., Li, S.M., Baltensperger, U., Holzer-Popp, T., Kinne, S., Pappalardo, G., Sugimoto, N., Wehrlic, C., Wiedensohle, A. and Zhang, X.Y. (2013). Recommendations for reporting black carbon measurements. Atmos. Chem. Phys. 13: 8365-8379. https://doi.org/10.5194/acp-13-8365-2013

Praveen, P.S., Ahmed, T., Kar, A., Rehman, I.H. and Ramanathan, V. (2012). Link between local-scale black carbon emissions in the Indo-Gangetic Plains and large scale atmospheric solar absorption. Atmos. Chem. Phys. 12: 1173-1187. https://doi.org/10.5194/acp-12-1173-2012

Pretorius, I., Piketh, S.J. and Burger, R.P. (2015). The impact of the South African energy crisis on emissions. WIT Trans. Ecol. Environ. 198: 255-264. https://doi.org/ 10.2495/AIR150211

R.M. Young Company (2020). Wind sensors and accessories, http://www.youngusa.com/products/1/

Ramachandran, S. and Rajesh, T.A. (2007). Black carbon aerosol mass concentrations over Ahmedabad, an urban location in western India: Comparison with urban sites in Asia, Europe, Canada, and the United States. J. Geophys. Res. 112: D06211. https://doi.org/10.1029/2006JD007488

Ramana, M.V., Ramanathan, V., Feng, Y., Yoon, S.C., Kim, S.W., Carmichael, G.R. and Schauer, J.J. (2010). Warming influenced by the ratio of black carbon to sulfate and the black-carbon source. Nat. Geosci. 3: 542-545. https://doi.org/10.1038/ngeo918

Roden, C.A., Bond, T.C., Conway, S. and Pinel, A.B.O. (2006). Emission factors and real-time optical properties of particles emitted from traditional wood burning cookstoves. Environ. Sci. Technol. 40: 6750-6757. https://doi.org/10.1021/es052080i

Saleh, R., Robinson, E.S., Tkacik, D.S., Ahern, A.T., Liu, S., Aiken, A.C., Sullivan, R.C., Presto, A.A., Dubey, M.K., Yokelson, R.J., Donahue, N.M. and Robinson, A.L. (2014). Brownness of organics in aerosols from biomass burning linked to their black carbon content. Nat. Geosci. 7: 647-650. https://doi.org/10.1038/ngeo2220

Sandradewi, J., Prèvót, A.S.H., Weingartner, E., Schmidhauser, R., Gysel, M. and Baltensperger, U. (2008). Study of wood burning and traffic aerosols in an Alpine valley using a multi-wavelength Aethalometer. Atmos. Environ. 42: 101112. https://doi.org/10.1016/j.atmosenv.2007.09.034

Satish, R., Shamjad, P., Thamban, N., Tripathi, S. and Rastogi, N. (2017). Temporal characteristics of brown carbon over the Central Indo-Gangetic Plain. Environ. Sci. Technol. 
51: 6765-6772. https://doi.org/10.1021/acs.est.7b00734

Schuster, G.L., Dubovik, O., Arola, A., Eck, T.F. and Holben, B.N. (2016). Remote sensing of soot carbon Part 2: Understanding the absorption Ångström exponent. Atmos. Chem. Phys. 16: 1587-1602. https://doi.org/10.51 94/acp-16-1587-2016

Schweizer, D., Cisneros, R. and Shaw, G. (2016). A comparative analysis of temporary and permanent beta attenuation monitors: The importance of understanding data and equipment limitations when creating $\mathrm{PM}_{2.5}$ air quality health advisories. Atmos. Pollut. Res. 7: 867-875. https://doi.org/10.1016/j.apr.2016.02.003

Scorgie, Y., Kneen, M.A., Annegarn, H.J. and Burger, L. (2003). Air Pollution in the Vaal Triangle: Quantifying source contributions and identifying cost-effective solutions. Clean Air J. 13: 5-18. https://doi.org/10.17159/ caj/2003/13/2.7152

Segura, S., Estellés, V., Titos, G., Lyamani, H., Utrillas, M.P., Zotter, P., Prèvot, A.S.H., Močnik, G., AladosArboledas, L. and Martinez-Lozano, J.A. (2014). Determination and analysis of in situ spectral aerosol optical properties by a multi-instrumental approach. Atmos. Meas. Tech. 7: 2373-2387. https://doi.org/10.519 4/amt-7-2373-2014

Smith, K.R., Jerrett, M., Anderson, H.R., Burnett, R.T., Stone, V., Derwent, R., Atkinson, R.W., Cohen, A., Shonkoff, S.B., Krewski, D., Pope Ш, C.A., Thun, M.J. and Thurston, G. (2009). Public health benefits of strategies to reduce greenhouse-gas emissions: Health implications of short-lived greenhouse pollutants. Lancet 374: 20912103. https://doi.org/10.1016/S0140-6736(09)61716-5

Srivastava, A.K., Singh, S., Pant, P. and Dumka, U.C. (2012). Characteristics of black carbon over Delhi and Manora Peak: A comparative study. Atmos. Sci. Lett. 13: 223-230. https://doi.org/10.1002/asl.386

Srivastava, A.K., Bisht, D.S., Ram, K., Tiwari, S. and Srivastava, M.K. (2014). Characterization of carbonaceous aerosols over Delhi in Ganga basin: Seasonal variability and possible sources. Environ. Sci. Pollut. Res. 21: 86108619. https://doi.org/10.1007/s11356-014-2660-y

Stockwell, C.E., Christian, T.J., Goetz, J.D., Jayarathne, T., Bhave, P.V., Praveen, P.S., Adhikari, S., Maharjan, R., DeCarlo, P.F., Stone, E.A., Saikawa, E., Blake, D.R., Simpson, I.J., Yokelson, R.J. and Panday, A.K. (2016). Nepal Ambient Monitoring and Source Testing Experiment (NAMaSTE): Emissions of trace gases and light-absorbing carbon from wood and dung cooking fires, garbage and crop residue burning, brick kilns, and other sources. Atmos. Chem. Phys. 16: 11043-11081. https://doi.org/10.5194/acp-16-11043-2016

Sun, H., Biedermann, L. and Bond, T.C. (2007). Color of brown carbon. A model for ultraviolet and visible light absorption by organic carbon aerosol. Geophys. Res. Lett. 34: L17813. https://doi.org/10.1029/2007GL029797

Tiwari, S., Srivastava, A.K., Chate, D.M., Safai, P.D., Bisht, D.S., Srivastava, M.K. and Beig, G. (2014). Impacts of the high loadings of primary and secondary aerosols on light extinction at Delhi during wintertime. Atmos. Environ. 92: 60-68. https://doi.org/10.1016/j.atmosenv.2
014.03.064

Tiwari, S., Dumka, U.C., Hopke, P.K., Tunved, P., Srivastava, A.K., Bisht, D.S. and Chakrabarty, R.K. (2016). Atmospheric heating due to black carbon aerosol during the summer monsoon period over Ballia: A rural environment over Indo-Gangetic Plain Impacts of the high loadings of primary and secondary aerosols on light extinction at Delhi during wintertime. Atmos. Res. 178179: 393-400. https://doi.org/10.1016/j.atmosres.2016.0 4.008

Tyson, P.D. and Preston-Whyte, R.A. (2000). The weather and climate of Southern Africa. Oxford University Press, Cape Town, South Africa.

Vaishya, A., Singh, P., Rastogi, S. and Babu, S.S. (2017). Aerosol black carbon quantification in the central IndoGangetic Plain: Seasonal heterogeneity and source apportionment. Atmos. Res. 185: 13-21. https://doi.org/10. 1016/j.atmosres.2016.10.001

Vakkari, V., Kerminen, V.M., Beukes, J.P., Tiitta, P., van Zyl, P.G., Josipovic, M., Venter, A.D., Jaars, K., Worsnop, D.R. and Kulmala, M. (2014). Rapid changes in biomass burning aerosols by atmospheric oxidation. Geophys. Res. Lett. 41: 2644-2651. https://doi.org/10.1002/2014GL059 396

Van der Berg, B., Piketh, S.J., Enslin, N., Burger, R.P., Beukes, P.J. and Van Zyl, P.G. (2015). Source apportionment of ambient particulate matter in Kwadela, Mpumalanga. NACA Conference, Bloemfontein, South Africa, http://hdl.handle.net/10394/21176

Verma, S.S. and Desai, B. (2008). Effect of meteorological conditions on air pollution of Surat City. J. Int. Environ. App. Sci. 3: 358-367. http://www.jieas.com/fvolumes/vo 1081-5/3-5-5.pdf

Wan, X., Kang, S., Li, Q., Rupakheti, D., Zhang, Q., Guo, J., Chen, P., Tripathee, L., Rupakheti, M., Panday, A.K., Wang, W., Kawamura, K., Gao, S., Wu, G. and Cong, Z. (2017). Organic molecular tracers in the atmospheric aerosols from Lumbini, Nepal, in the northern IndoGangetic Plain: Influence of biomass burning. Atmos. Chem. Phys. 17: 8867-8885. https://doi.org/10.5194/acp17-8867-2017

Weingartner, E., Saathoff, H., Schnaiter, M., Streit, N., Bitnar, B. and Baltensperger, U. (2003). Absorption of light by soot particles: Determination of the absorption coefficient by means of aethalometers. J. Aerosol Sci. 34: 1445-1463. https://doi.org/10.1016/S0021-8502(03)003 59-8

Wu, D., Mao, J., Deng, X., Tie, X., Zhang, Y., Zeng, L., Li, F., Tan, H., Bi, X., Huang, X., Chen, J. and Deng, T. (2009). Black carbon aerosols and their radiative properties in the Pearl River Delta region. Sci. China Ser. D 52: 1152-1163. https://doi.org/10.1007/s11430-0090115-y

Wu, Y., Yan, P., Tian, P, Tao, J., Li, L., Chen, J., Zhang, Y., Cao, N., Chen, C. and Zhang, R. (2015). Spectral light absorption of ambient aerosols in urban Beijing during summer: An inter-comparison of measurements from a range of instruments. Aerosol Air Qual. Res. 15: 11781187. https://doi.org/10.4209/aaqr.2014.09.0224 
Yan, C., Zheng, M., Bosch, C., Andersson, A., Desyaterik, Y., Sullivan, A.P., Collet, J.L., Zhao, B., Wang, S., He, K. and Gustafsson, Ö. (2017). Important fossil fuel contribution to brown carbon in Beijing during winter. Sci. Rep. 7: 43182. https://doi.org/10.1038/srep43182

Yang, M., Howell, S.G., Zhuang, J. and Huebert, B.J. (2009). Attribution of aerosol light absorption to black carbon, brown carbon, and dust in China-interpretations of atmospheric measurements during EAST-AIRE. Atmos. Chem. Phys. 9: 2035-2050. https://doi.org/10.5194/acp9-2035-2009

Zhang, K.M., Allen, G., Yang, B., Chen, G., Gu, J., Schwab, J., Felton, D. and Rattigan, O. (2017). Joint measurements of
$\mathrm{PM}_{2.5}$ and light-absorptive PM in wood smoke dominated ambient and plume environments. Atmos. Chem. Phys. 17: 11441-11452. https://doi.org/10.5194/acp-17-11441-2017 Zhou, X., Gao, J., Wang, T., Wu, W. and Wang W. (2009). Measurement of black carbon aerosols near two Chinese megacities and the implications for improving emission inventories. Atmos. Environ. 43: 3918-3924. https://doi.org/ 10.1016/j.atmosenv.2009.04.062

Received for review, September 9, 2019

Revised, May 25, 2020

Accepted, June 8, 2020 